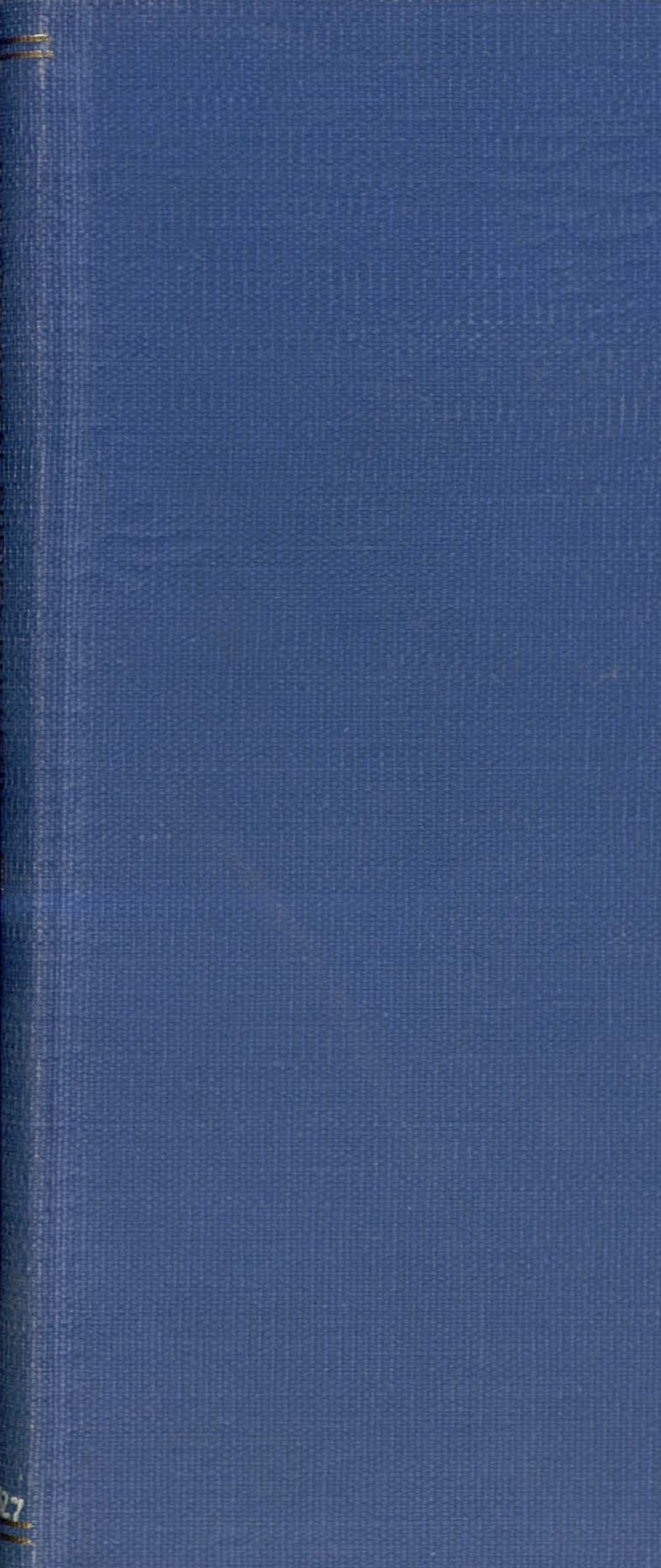









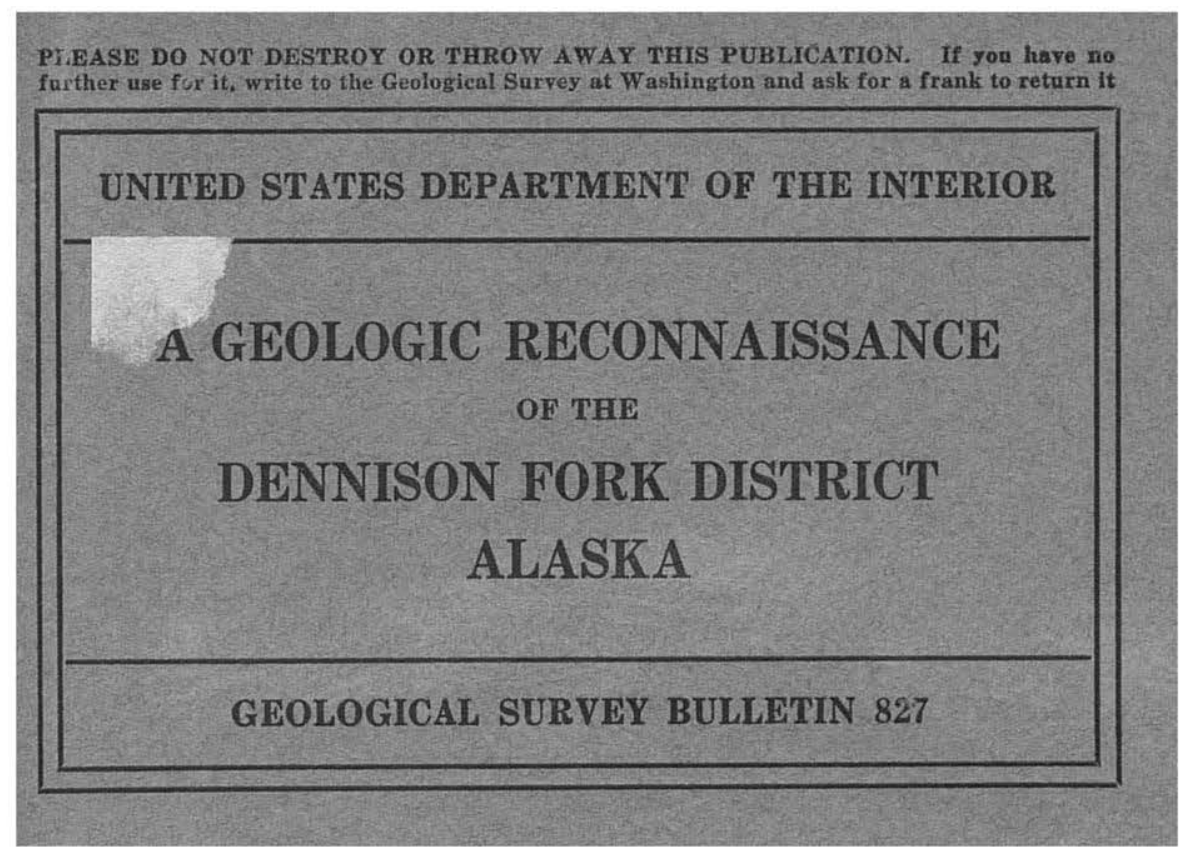



UNITED STATES DEPARTMENT OF THE INTERIOR

Ray Lyman Wilbur, Secretary

[U.S.] GEOLOGICAL SURVEX

Bulletin 827

\section{A GEOLOGIC REGONNAISSANGE OF THE DENNISON FORK DISTRICT \\ ALASKA}

BY

J. B. MERTIE, JR.

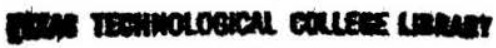

unopex, Ters

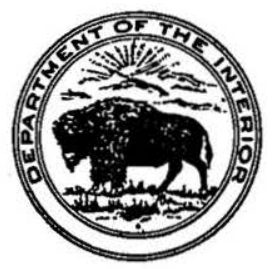

LIBFT:ARY

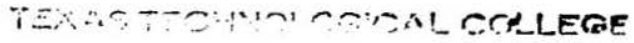

L... $\quad \therefore \therefore \therefore$

UNITED STATES

GOVERNMENT PRINTING OFFICE

WASHINGTON : 1931

For sale by the Superintendent of Documents, Washington, D. C. - - - - Price 45 cents 



\section{CONTENTS}

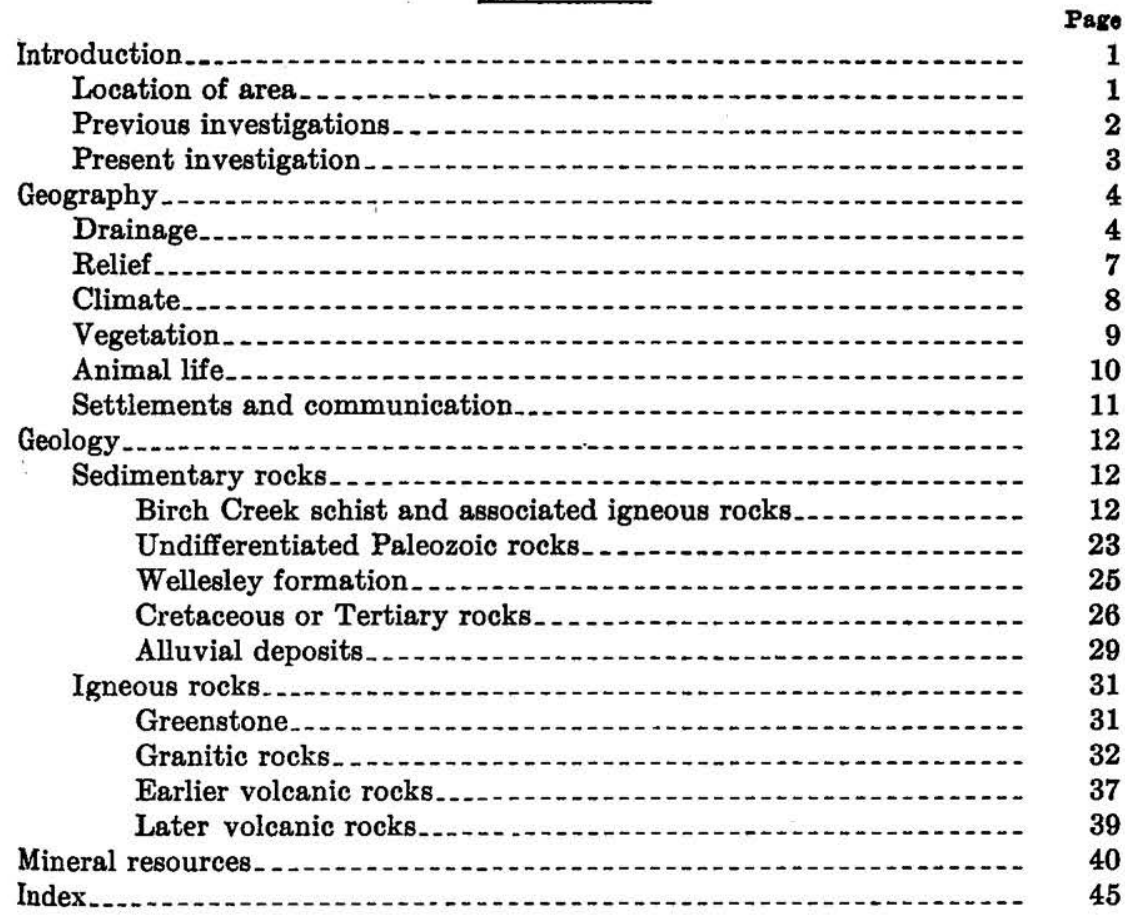

\section{ILLUSTRATIONS}

Page

Plate 1. Topographic map of the Dennison Fork district........... In pocket.

2. Geologic map of the Dennison Fork district.............. In pocket.

3. $A$, Lower valley of Dennison Fork; $B$, Lower valley of Liberty Creek; $C$, Upper valley of Dennison Fork, showing broad, flat valley floor

4. A, Broad lower valley of George Creek where it joins the Tanana River; $B$, Mount Fairplay from the northwest and the massif surrounding it.

5. $A$, Panoramic view looking northeast from head of George Creek; $B$, Valley of Mosquito Fork, looking upstream from confluence with Dennison Fork

6. A, Chicken from the east; B, Typical outcrop of Pelly gneiss along ridge top; $C$; Lower valley of Chicken Creek at its junction with Mosquito Fork ... 
Plate 7. $A$, Augen gneiss, a phase of the Pelly gneiss; $B$, Augen gneiss interlaminated with quartzite schist........................

8. A, Pelly gneiss intruded by Mesozoic granitic rocks; $B$, Volcanic cone, East Fork of Dennison Fork ..................

Figure 1. Index map showing location of the Dennison Fork district...-

2. Sketch map showing routes of traverses made by Brooks, Prindle, and Mertie.....

3. Sketch map showing distribution of timber in the Dennison Fork district.......

Page

4 


\title{
A GE0LOGIC RECONNAISSANCE OF THE DENNISON FORK DISTRICT, ALASKA
}

\author{
By J. B. MeRTie, Jr.
}

\section{INTRODUCTION}

LOCATION OF AREA

The Dennison Fork district is a triangular area of about 6,700 square miles lying south of the sixty-fourth parallel, west of the one hundred and forty-first meridian, and north of the Tanana River. Its

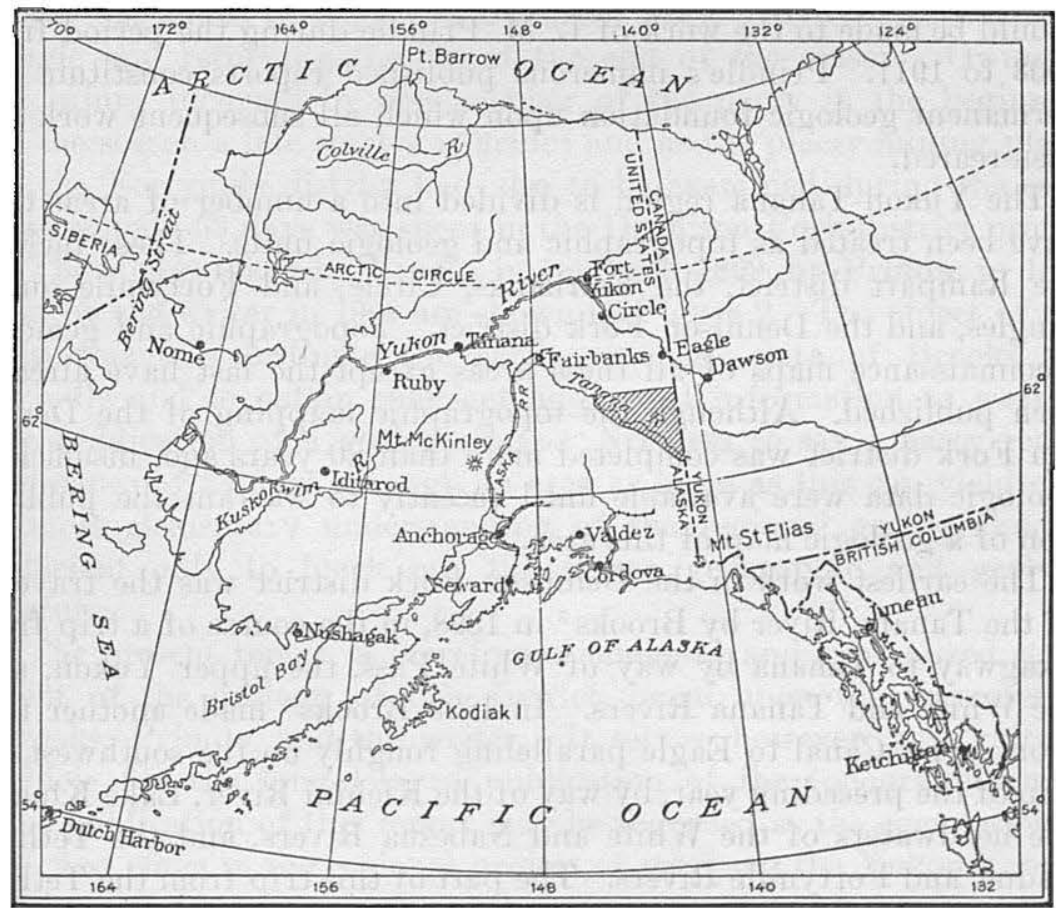

Figunn 1.-Index map showing location of the Dennison Fork district

location in Alaska is shown in Figure 1. This district is part of a larger geographic unit known as the Yukon-Tanana region, about 40,000 square miles in extent, which includes that part of Alaska lying between the Yukon and Tanana Rivers. 


\section{PREVIOUS INVESTIGATIONS}

A topographic and geologic reconnaissance of the Yukon-Tanana region is a major project which has engaged the attention of the United States Geological Survey for many years. Topographic mapping on a scale of $1: 250,000$ was begun in the Fortymile quadrangle by E. C. Barnard in 1898, and the remainder of the Yukon-Tanana region was mapped in 1902 to 1910 by T. G. Gerdine, D. C. Witherspoon, R. B. Oliver, J. W. Bagley, and G. T. Ford. The geologic mapping may be said to date from the earliest traverses of the Yukon and Tanana Rivers, by Spurr ${ }^{1}$ and Brooks, ${ }^{2}$ respectively, in 1896 and 1898; and geologic work has been continued intermittently to the present day by A. H. Brooks, A. J. Collier, L. M. Prindle, J. B. Mertie, jr., G. C. Martin, R. M. Overbeck, Eliot Blackwelder, and others. As this report is not a general treatise on the Yukon-Tanana region, it is unnecessary to give the rather lengthy geologic bibliography of the reports made by these men. Special reference, however, should be made to the work of L. M. Prindle during the period from 1903 to 1911. Prindle's numerous published reports constitute the permanent geologic foundation upon which all subsequent work has been reared.

The Yukon-Tanana region is divided into a number of areas that have been treated as topographic and geologic units. These include the Rampart district, the Fairbanks, Circle, and Fortymile quadrangles, and the Dennison Fork district. Topographic and geologic reconnaissance maps of all these areas except the last have already been published. Although the topographic mapping of the Dennison Fork district was completed more than 20 years ago, insufficient geologic data were available until recently to warrant the publication of a geologic map of this area.

The earliest work in the Dennison Fork district was the traverse of the Tanana River by Brooks ${ }^{3}$ in 1898, in the course of a trip from Skagway to Tanana by way of White Pass, the upper Yukon, and the White and Tanana Rivers. In 1899 Brooks ${ }^{4}$ made another trip from Lynn Canal to Eagle paralleling roughly on the southwest his trip of the preceding year, by way of the Klehini River, Lake Kluane, the headwaters of the White and Nabesna Rivers, and the Tetling, Ladue, and Fortymile Rivers. The part of this trip from the Tetling

\footnotetext{
${ }^{1}$ Spurr, .T. E., Geology of the Yukon gold district, Alaska : U. S. Geol. Survey Eighteenth Ann. Report., pt. 3, pp. 87-392, 1898.

Brooks, A. H., A reconnaissance in the Tanana and White river basins, Alaska, in 1898 : U. S. Geol. Surrey Twentieth Ann. Rept., pt. 7, pp. 431-509, 1900.

Brooks, A. H., op. cit.

- Brooks, A. H., A reconnaissance from Pyramid Harbor to Eagle City, Alaska, including a description of the copper deposits of the upper White and Tanana Rivers: U. S. Geol. Survey Twenty-flrst Ann. Rept., pt. 2, pp. 331-391, 1901.
} 
River to Eagle constituted the first traverse across the Dennison Fork district proper. In $1905 \mathrm{~L}$. M. Prindle made a geologic traverse from Eagle to Fairbanks, in the course of which he traversed about 200 miles through the area here designated the Dennison Fork district, but no report of that work was published. The thin sections of the igneous and metamorphic rocks of the Dennison Fork district collected in 1905, however, were subsequently studied by the writer; for comparison with similar rocks in the Circle quadrangle, to the north.

A report by Cockfield ${ }^{5}$ upon a contiguous area in Canada should also be mentioned, for his work was of a semidetailed nature, and the report has been most helpful as a source of additional information along the eastern limits of the Dennison Fork district.

\section{PRESENT INVESTIGATION}

During the season of 1928 the writer made another traverse of about 325 miles through the Dennison Fork district, starting from Eagle and returning thereto at the end of the season. Owing to an injury incurred by one member of the party in the beginning of the season a late start was made; and as the placer-mining plants in the Fortymile district had also to be examined during the same season, only 53 days was spent in the Dennison Fork district proper.

The routes taken by Brooks in 1898 and 1899, by Prindle in 1905, and by the writer in 1928 are shown in Figure 2. The object of this trip was to coordinate the earlier geologic data of Brooks and Prindle and to obtain sufficient additional information to warrant the publication of a geologic map. Needless to say a hasty reconnaissance of 53 days through an area as large as this can yield only a most elementary understanding of the regional geology and is sufficient only to block out the larger geographic and geologic features.

The present report is therefore a summary and generalized statement of the geology of this district, based upon the traverses of Brooks, Prindle, and the writer. It serves, however, as a suitable vehicle for the long-delayed publication of the topographic map. The publication of this report may be regarded as the completion of the first stage in the regional project of mapping the Yukon-Tanana region. Subsequent work in this region will be devoted to more detailed studies of the geology and mineralization.

- Cockfield, W. E., Sixtymile and Ladue Rivers area, Yukon Territory, Canada: Canada Geol. Survey Mem. 123, 1921. 


\section{GEOGRAPHY}

\section{DRAINAGE}

This district is drained by tributaries of the Yukon and Tanana Rivers, but mainly by those of the Yukon, although it is much closer geographically to the Tanana. In fact, for over 50 miles within this district the Yukon-Tanana watershed is nowhere more than 9 miles and at one place only 2 miles from the Tanana River; the average distance is perhaps 5 miles. The Yukon River, on the other hand,

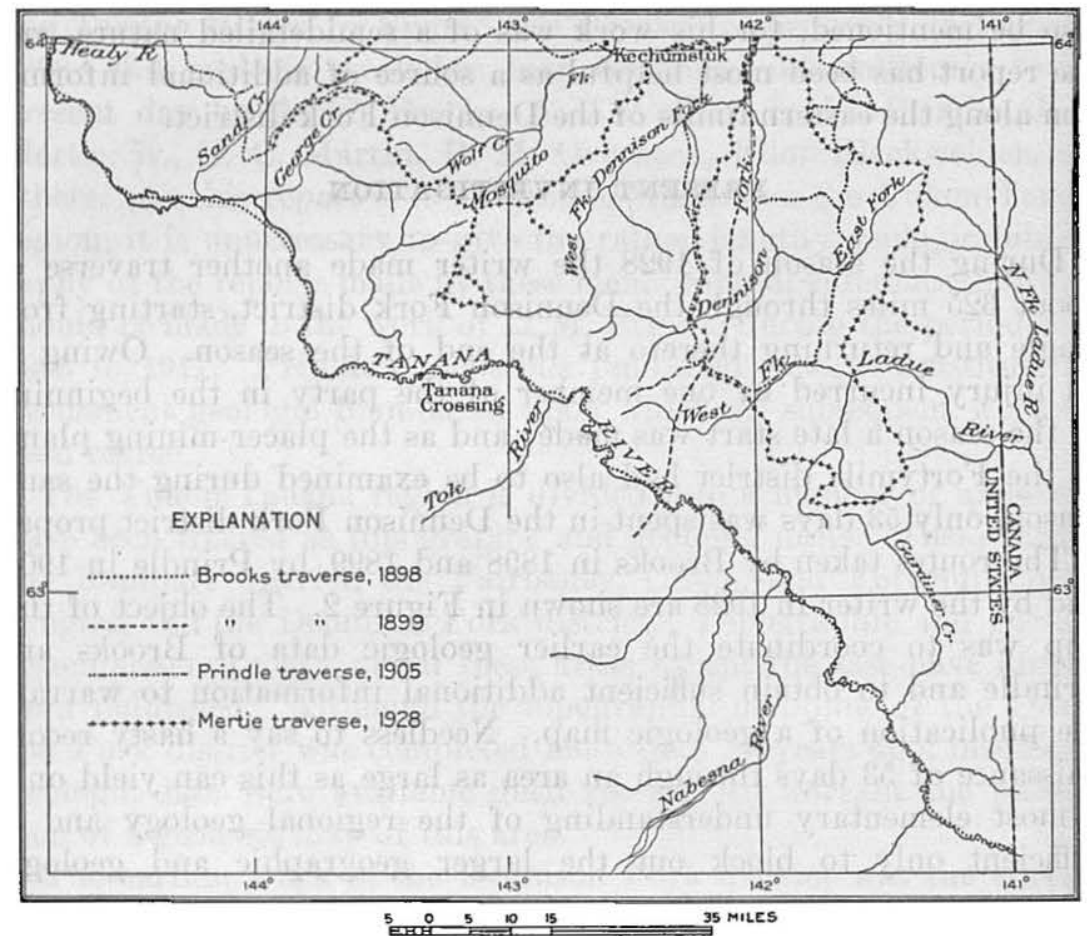

Figure 2.-Sketch map showing routes of traverses made by Brooks, Prindle, and Mertie

lies 100 miles to the northeast. The origin of this anomalous watershed in the Dennison Fork district and the history of the streams that drain from it toward both rivers constitute special physiographic problems of great interest, the solution of which will be obtained only by more detailed studies.

The Fortymile, Ladue, and Sixtymile Rivers are the streams that drain northeastward from this district into the Yukon River. The Fortymile River and its tributaries drain nearly two-thirds of the area northeast of the main watershed, the Ladue River nearly a third, and the Sixtymile River less than 2 per cent. The Mosquito and Dennison Forks of the Fortymile River, which are the only 
Fortymile tributaries in this district, are characterized by: wide, flat valleys in their upper courses, particularly near the Tanana and Ladue River divides. These open headwater valleys are lake dotted, swampy, and for the most part timber covered and present great difficulty to summer travel with horses, although they are ideal for winter travel by dog sled. They range in width at different places from 1 to 10 miles; the widest one is the valley of the Mosquito Fork of the Fortymile at the point where it is joined by Wolf Creek. Another conspicuous example is the valley of the Dennison Fork of the Fortymile, which is 6 miles /or more in width at the point where it is joined by its East Fork. Plate 3, $C$, shows the flats of Dennison Fork, looking downstream. The divides between these headwater tributaries also are for the most part wide, open, swampy saddles-for example, the divide between the West Fork of the Dennison Fork and the Mosquito Fork, on the one hand, and the main Dennison Fork on the other. The streams in these upper stretches flow for the most part in narrow channels between steeply cut banks of silt and over beds of silt and vegetal material interspersed at places with small and imperfectly developed gravel bars. Of all the headwater tributaries, only one, a tributary of Wolf Creek, heading against Sand Creek, is a typical mountain stream, characterized by a high gradient and well-developed gravel and boulder bars; and in going downstream this character changes 10 miles before the main Wolf Creek is reached.

The Mosquito and Dennison Forks of the Fortymile emerge from these headwater flats into narrow constricted valleys downstream. At these points of change the stream gradients become higher, resulting in the formation of narrow, incised valley floors. The headwater valley gradients persist, however, and are represented by river terraces which become more and more conspicuous downstream. The streams in these lower, later valleys of higher gradient flow along as normal mountain streams, stretches of sluggish water alternating with riffles where the water flows swiftly over coarse cobbles and boulders. Plate $3, A$, shows the character of the Dennison Fork below its forks, where it flows in such a constricted valley, and Plate $3, B$, shows a similar type of drainage, as exemplified by Liberty Creek.

The tributaries of the Ladue River that drain this district are similar in some respects to the headwater tributaries of the Mosquito and Dennison Forks of the Fortymile, but markedly different in others. The larger streams, for example, flow for the most part between steeply cut banks and have only imperfectly developed gravel bars. The valleys, on the other hand, are rather sharply incised, and the streams in general, particularly in their extreme headwaters, have higher gradients. Indeed, some of these streams in their extreme 
headwaters flow very swiftly in narrow channels paved with gravel but bounded by steep cut banks of finer sedimentary and vegetal material which, though moved into the streams by the force of solifluxion, is carried away as rapidly as it accumulates. The physiographic difference between the valley of the Ladue River and the headwater valleys of the Mosquito and Dennison Forks of the Fortymile will instantly be revealed by an inspection of the topographic map of this district. (See pl. 1.)

The area southwest of the Yukon-Tanana watershed is drained in reality by the Tanana River. At the southeast corner of this district three small streams, Mirror, Scottie, and Gardiner Creeks, named in order downstream, drain to the Tanana. In the northwestern part of this district Mansfield, George, and Sand Creeks and the Healy River, also named in order downstream, flow to the Tanana. Midway between these two groups of streams the Yukon-Tanana watershed is so close to the Tanana River that only short stream courses have developed. All the streams of this district flowing to the Tanana have abnormally steep headwater gradients but relatively Jow gradients farther downstream. Hence the upper valley slopes are steep and impinge abruptly against flatter and broader valley floors below. Some of these headwater gulches are so steeply ineised that they present a superficial resemblance to glacial cirques; and they contrast markedly with the broad, open low-gradient valley floors of the streams that drain northeastward to the Yukon. Plate 4, $A$, is a view looking down the valley of George Creek and shows the broad valley of this creek, where it joins with the valley of the Tanana.

The Tanana from the mouth of the Nabesna downstream receives a number of large tributaries from the southwest, which in order downstream are the Kalukna, Tetling, Tok, Robertson, Johnson, and Gerstle Rivers. Of these the Robertson and Johnson Rivers, like the Chisana and Nabesna, are swift mud-laden streams of glacial origin, and such streams stand in strong contrast with the small sluggish clear-water creeks that enter the Chisana and Tanana Rivers from the northeast.

The Tanana from Scottie Creek downstream follows the northeast wall of the valley, except for a short distance below the Tetling River, where the Tanana swings in to the southwest side of the valley. The Chisana and the Tanana below Tanana Crossing are swift braided streams, but the Tanana above Tanana Crossing is confined for the most part to one channel and is meandering and in places sluggish. In this stretch the river flows in a broad gravelfloored valley, which attains a maximum width of 20 miles or more. At the Tetling River the valley becomes suddenly constricted to a 
width of 4 miles, then gradually widens downstream to Tanana Crossing, below which it is only 2 miles wide. Tanana Crossing, about 20 miles in an air line below the mouth of the Tok River, is regarded as the head of navigation for light-draft power boats at ordinary stages of water, but small steamboats were taken well up into the upper Tanana River at the time of the Chisana stampede. Two stretches of rapid water on the Tanana, one a short distance below Tanana Crossing and the other below the mouth of the Robertson River, have been named respectively the Cathedral and Tower Bluff Rapids. Neither of these rapids is regarded as particularly dangerous to navigation.

\section{RELIEF}

The Tanana River at the mouth of the Healy River flows at an altitude of about 1,300 feet above sea level, and this is the lowest point in this district. The Ladue River at the international bounary has an altitude of about 1,500 feet, and the Dennison Fork, at the north edge of the district, about 1,400 feet. The highest point in the district is Mount Fairplay, which is about 5,500 feet above sea level. The maximum relief is therefore about 4,200 feet. The average relief, however, from the valley floors of the Mosquito and Dennison Forks and the Ladue River to the adjoining ridge tops, is from 1,500 to 2,500 feet.

This district, like the rest of the Yukon-Tanana region, is part of the central plateau of interior Alaska and is an upland country, characterized by more or less even-topped ridges, which rise to altitudes of 2,500 to 4,000 feet. Plate 5, A, looking northeast from the head of George Creek, shows the character of this upland type of country. Long smooth spurs lead from the main ridges down to the master streams. For the most part these ridges and spurs are separated from one another by narrow valleys, but the Mosquito and Dennison Forks of the Fortymile have developed in their headwaters wide valleys about 2,000 feet above sea level, which serve to diversify this otherwise monotonous ridge topography. Nearly everywhere these smooth ridge tops afford excellent footing for men and horses and therefore constitute the usually traveled summer routes. In this part of the Yukon-Tanana region the ridges have no uniform trend. A topographic anomaly worthy of special mention is the fact that the main Yukon-Tanana watershed has an average altitude between 2,500 and 3,000 feet and is therefore much lower than many of the intervalley ridges farther northeast. This low watershed, however, so close to the Tanana is a local feature and not characteristic of the Yukon-Tanana region in general; for to the northwest large rivers like the Goodpaster, Salcha, and Chena dis- 
charge southwestward into the Tanana, and the main watershed lies in higher country which is nearly equidistant from the Yukon and Tanana Rivers.

Throughout the Yukon-Tanana region isolated peaks and domes stand up above the average ridge level, making prominent landmarks. The sharp peak of Mount Fairplay is easily the most striking topographic feature in this area and is visible for many miles in all directions. Plate $4, B$, is a near view of Mount Fairplay from the northwest, showing also the group of high hills which surround it and constitute the Mount Fairplay igneous massif. Taylor Mountain, 20 miles north of Mount Fairplay, and Kechumstuk Mountain, 30 miles northwest of Mount Fairplay, are two such highlands, but few of the others have received names. Taylor Mountain appears in the background of Plates 5, $B$, and 6, $C$.

\section{CLIMATE}

This district has the typical sub-Arctic climate of interior Alaska, characterized by long cold winters and short but fairly warm summers. Climatic records were formerly kept by United States Weather Bureau observers at Kechumstuk and Tanana Crossing, within this district, and at Chicken and at a station on the North Fork of the Fortymile River, just north of this district, but the observations have now been discontinued. The climate of the YukonTanana region is known, however, in a general way from similar observations made by the Weather Bureau at Eagle, Circle, Fort Yukon, Rampart, Tanana, and Fairbanks; and all available records indicate that the annual precipitation is about 11 inches, of which about 30 per cent falls as snow. This average, however, is taken from the records of stations below 1,000 feet in altitude, and probably the precipitation in the mountainous areas is somewhat higher.

The mean temperature of the Yukon-Tanana region ranges from about $60^{\circ}$ for the month of July to about $-17^{\circ}$ for January; but a maximum summer temperature of $100^{\circ}$ at Fort Yukon and a minimum winter temperature of $-76^{\circ}$ at Tanana have been recorded by the Weather Bureau. In general about 53 days in the year may be expected when the temperature will rise to $70^{\circ}$ or higher and about 125 days may be expected when the temperature will fall to zero or below.

The summers vary in character from year to year but for the most part are characterized by much fine weather. Thunderstorms often come in June and July, and some few summers have included protracted periods of cloudy or rainy weather, but in general the precipitation is so light as to classify this as a semiarid region. The rather dense regetation on the lower hill slopes and in the valleys 
seems to belie this classification, but it results from the fact that most of the precipitation is absorbed by heavy mosses, which hold the water close to the surface. Also most of the alluvial deposits awiay from the main watercourses are frozen to great depths; thus restricting the subsurface circulation and still further tending to hold the water at the surface.

\section{VEGETATION}

Many varieties of plants flourish in the Dennison Fork district, but no plant collections were made by the writer. Vegetation is thickest on the alluvial valley floors, particularly close to the watercourses, where willows, alders, and other plants form a dense bushy undergrowth and timber reaches good size. Just above the valley floors, in the lower parts of spurs extending into the valleys, dense thickets of small spruce are usually found. Farther up the slopes the trees become scarcer and the underbrush thins out. Timber line is about 2,500 feet above sea level, but at the southwest side of this district, near the Tanana, it is closer to 3,000 feet. Above timber line grass, mosses, and low bushes still persist for another 1,000 feet. Just above timber line the dwarf black birch grows in places as a thick underbrush, known locally as " buck brush."

Spruce, poplar, and birch are the common trees. Spruce is the most plentiful, ranging from the valley floors up to timber line. Spruce trees 18 inches or more in diameter are found in the lower valleys, and such timber affords an adequate source of logs and lumber for local needs. Figure 3 shows the approximate distribution of timber in this district. Higher on the hill slopes the spruce becomes smaller and more gnarly and has little usefulness except perhaps for firewood. Poplar and white birch grow mainly on the upper hill slopes. A little tamarack also is found in the valleys draining to the Tanana. One of the serious problems of this region is the prevalence of forest fires. A large part of this district has at one time or another been burned over, so that the supply of really good timber is now rather meager. Also, the destruction of the mosses by fire has removed in considerable measure the regional sponge that formerly conserved the water supply. Hence many of the streams-for example, the forks of the Ladue River-carry very little water in summer-so little, in fact, that it is difficult to see how placer deposits could be sluiced during the summer in that area, if any were discovered.

Grass for horses is obtained in the valley bottoms, along the streams, and also at the upper edge of timber line, particularly on southward-facing slopes. Some prospectors and miners have stated that the burning of an area favors the subsequent growth 
of grass, but this appears to be in fact far from the truth. No good purpose is served by the destruction of forests by fire.

Edible berries are also common, of which the blueberry is perhaps most prized, for it matures about July 20 and serves as fresh fruit during the following six weeks. Low-bush cranberries also are very plentiful, but these, maturing the last of August, are more in the nature of a winter fruit. At some places, mainly in the vicinity of settlements, red raspberries are found. Small gardens are raised wherever settlements exist, and potatoes, turnips, cabbage, lettuce, rhubarb, beets, carrots, and radishes are grown without difficulty.

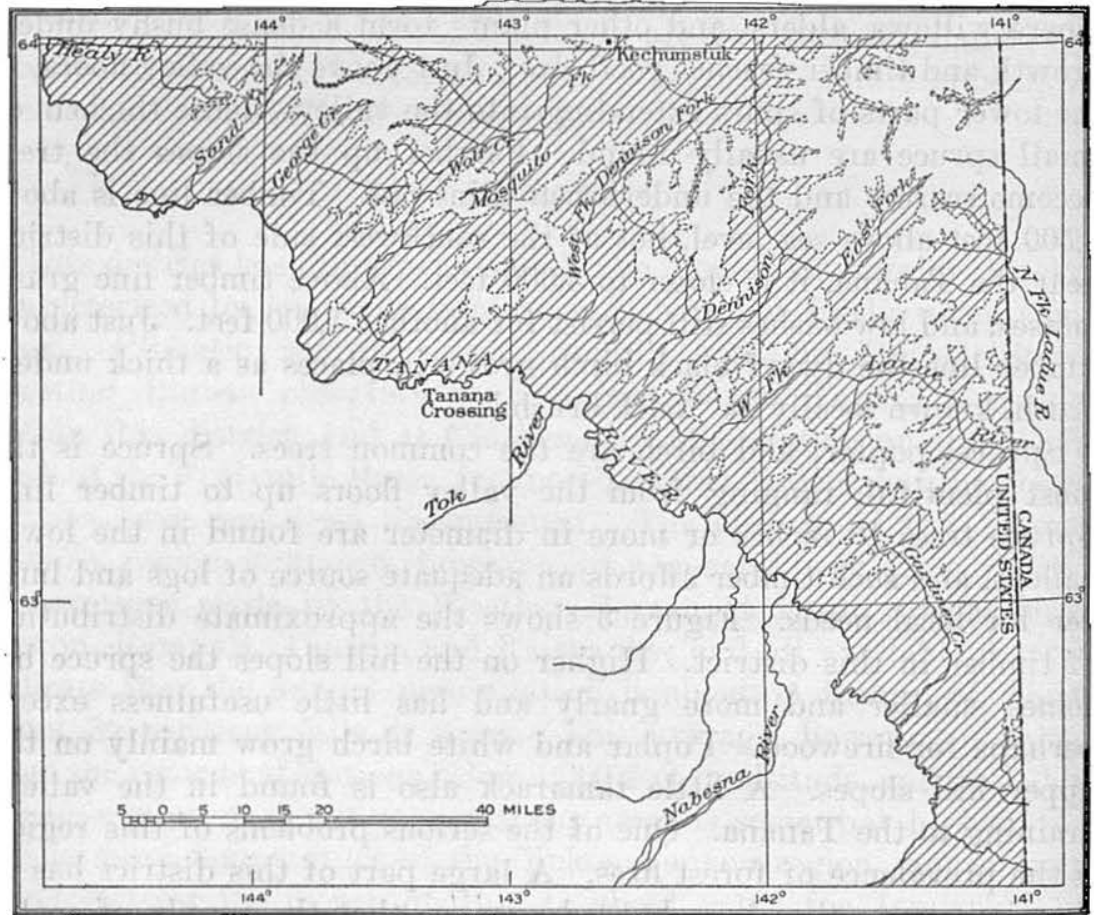

FiguRn 3.-Sketch map showing distribution of timber in the Dennison Fork district. Area south of the Tanana River unmapped

Tomatoes and cucumbers are also raised in a little hothouse at Chicken.

\section{ANTMAL LIFE}

Caribou, moose, and bear are the more common of the larger game animals of this district, and the caribou and moose constitute an important source of food for the residents. Sheep appear to be absent in this area. The caribou assemble in large bands in August and migrate across the country in herds of thousands, and the spectacle of such a passing band is one of the impressive sights of the country. Moose are found mainly in the large valleys, where the 
ground is swampy and lakes are abundant. Black bears are fairly numerous everywhere, and in the higher hills the great grizzly bear is found.

Numerous fur-bearing animals also live in this district, including the wolf, coyote, fox, lynx, marten, squirrel, weasel, beaver, and mink. Other animals, such as porcupines, rabbits, and mice, are also found. The winter of 1927-28 was a particularly good one for trappers of lynx.

The native game birds are ptarmigan and grouse, but in summer migratory.game birds, such as ducks and geese, also visit the country. Many other varieties of birds have been recognized in this district. Grayling, or Arctic trout, are the principal fish that inhabit the streams.

\section{SETTLEMENTS AND COMMUNICATION}

The only settlement of white people in the Dennison Fork district is at Tanana Crossing, on the north side of the Tanana about 20 miles in an air line below the mouth of the Tok River. An Episcopal mission was formerly located at Tanana Crossing, but now this settlement consists only of a few traders. Chicken, one of the mining communities of the Fortymile district, lies just north of the Dennison Fork district and at the present time is the nearest white settlement of any size to this district. About 50 people live at and about Chicken. Plate 6, $A$, is a view of Chicken from the east.

There are two native villages in this district. One of them, Mansfield, is about 4 miles north of Tanana Crossing, at the north edge of the Tanana Valley floor. As a matter of fact, most of the Mansfield natives now live at or near Tanana Crossing, but in their hunting season they go back and forth to Mansfield and to Mansfield Lake. The other native village is Kechumstuk, on Kechumstuk Creek near its junction with the Mosquito Fork of the Fortymile. One white man also has a cabin at Kechumstuk and a homestead farther up the Mosquito Fork where he puts up hay in summer for the use of his own and other stock at Chicken during the winter.

The Dennison Fork district at present may be approached by trail from Eagle; by boat from Fortymile, Y. T., to Steel Creek and thence southward by trail; or by boat up the Tanana to Tanana Crossing. The district is practically without any white settlements and is inhabited only by a few natives and in winter by a few white trappers. The mail for Tanana Crossing was formerly distributed from Eagle and carried through this district by way of the Mosquito Fork and the head of the West Fork of the Dennison Fork, but this service has been discontinued for several years.

Although this district is practically unpopulated, it is nevertheless of interest to record the conditions of transportation at Chicken, the 
nearest settlement of any size. The winter freight rate from Eagle to Chicken is from 6 to 7 cents a pound, and the summer rate 25 cents a pound. From Fortymile, Y. T., to Chicken by way of the Fortymile River and Steel Creek the winter rate is 5 cents a pound, and much of the freight for Chicken enters by this route. Neither of these two routes is particularly suitable, either for Chicken or for the Dennison Fork district. The Eagle-Chicken trail crosses several drainage systems and has a number of hard climbs, so that it is a difficult trail both in summer and in winter. The Fortymile-Steel Creek route, or any other route from Fortymile, Y. T., has disadvantages caused by the detention of goods for inspection or payment of duty before crossing the international boundary. Two airplane landing fields are now available at and near Chicken, and it would seem that a part of the freight for this district might economically be transported by this method. Plate 6, $C$, with Taylor Mountain in the background, also shows the site of the new airplane landing field at Chicken. If the Fortymile district in general is to have a revival of mining on a large scale, similar to the Fairbanks district, a good truck road should be built to connect with Grundler, the nearest point on the Richardson Highway, thus establishing connection with the Alaska Railroad.

\section{GEOLOGY}

\section{SEDIMENTARY ROCKS}

BIRCH CREEK SOHIST AND ASSOCIATED IGNEOUS ROCKS

\section{DISTRIBUTION}

The Birch Creek schist and associated metamorphic rocks of igneous origin form much of the bedrock in the eastern part of the Dennison Fork district, in the basins of the East Fork of the Dennison Fork of the Fortymile and the Ladue and Sixtymile Rivers. Connecting with this main area, a smaller belt extends westward across the valleys of the West Fork of the Dennison Fork and the Mosquito Fork of the Fortymile and thence across Mansfield, George, and Sand Creeks to the Healy and Tanana Rivers. Two smaller outlying masses lie to the north, one centering around Kechumstuk Mountain and the other at the head of a northwest tributary of Wolf Creek.

The exact boundaries of the Birch Creek schist have been inferred rather than accurately drawn at many places and therefore are to some extent diagrammatic. This is unavoidable where geologic mapping is based upon two or three linear traverses in an area as large as this. The contact lines between the Birch Creek schist and adjoining formations are particularly weak at the south and west 


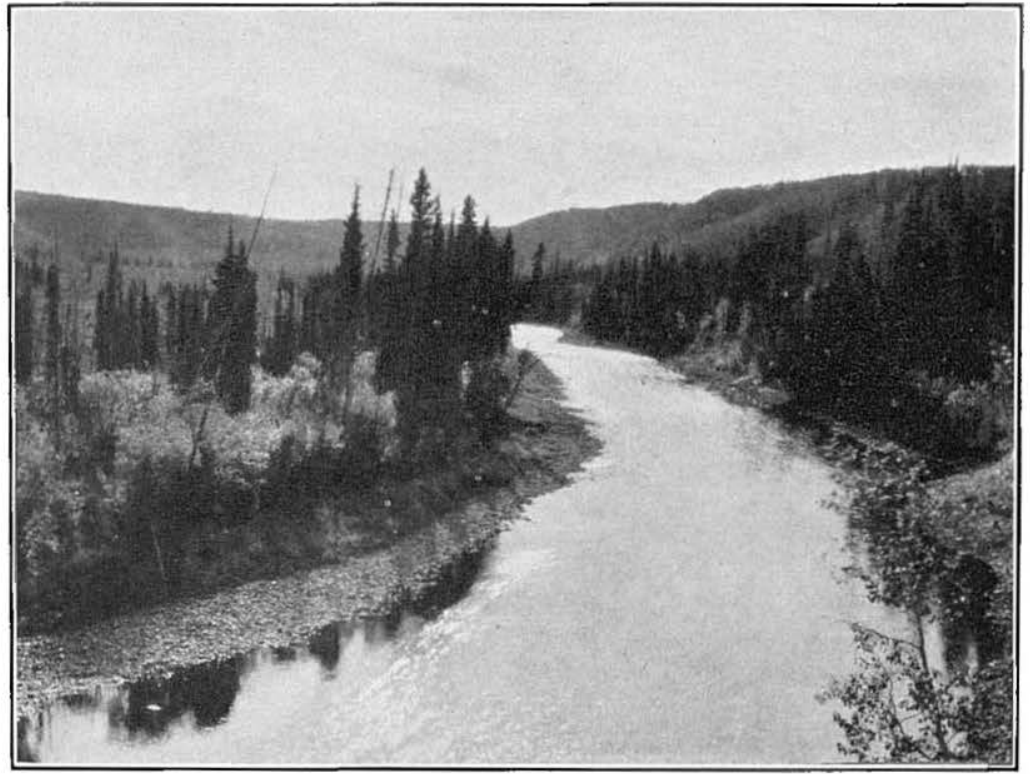

A. LOWER VALLEY OF DENNISON FORK

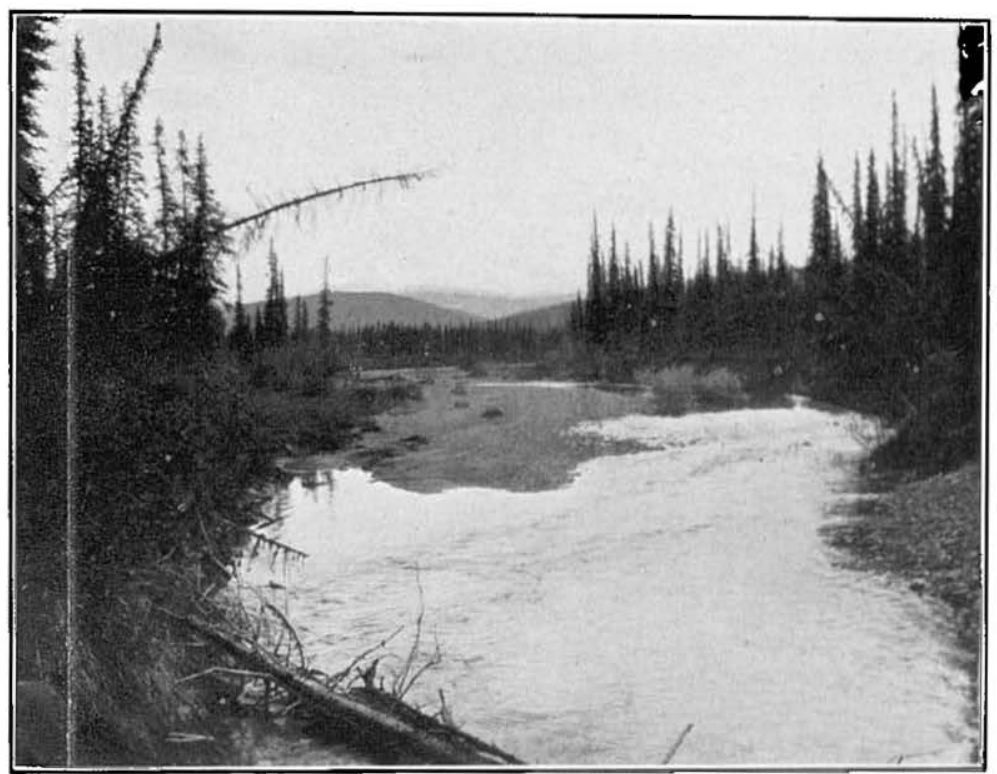

B. LOWER VALLEY OF LIBERTY CREEK

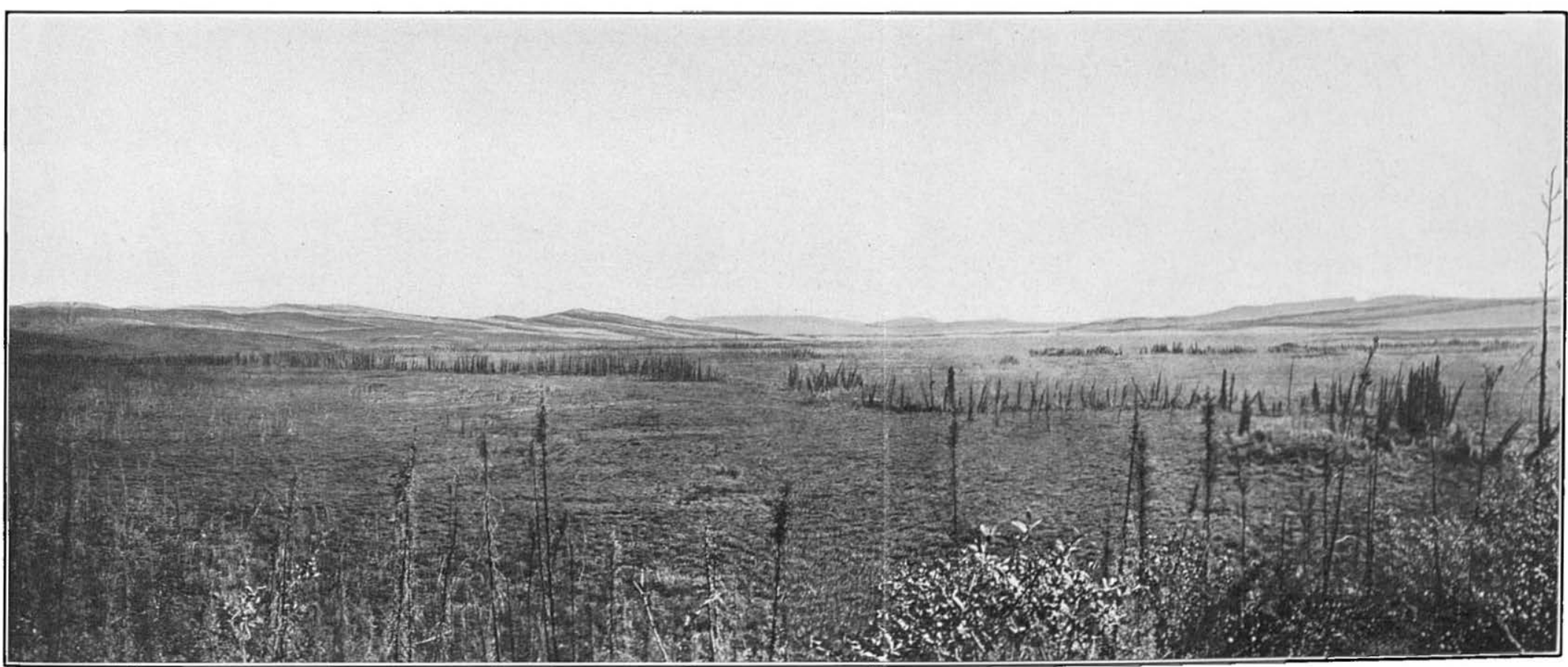

C. UPPER VALLEY OF DENNISON FORK, SHOWING BROAD, FLAT VALLEY FLOOR 



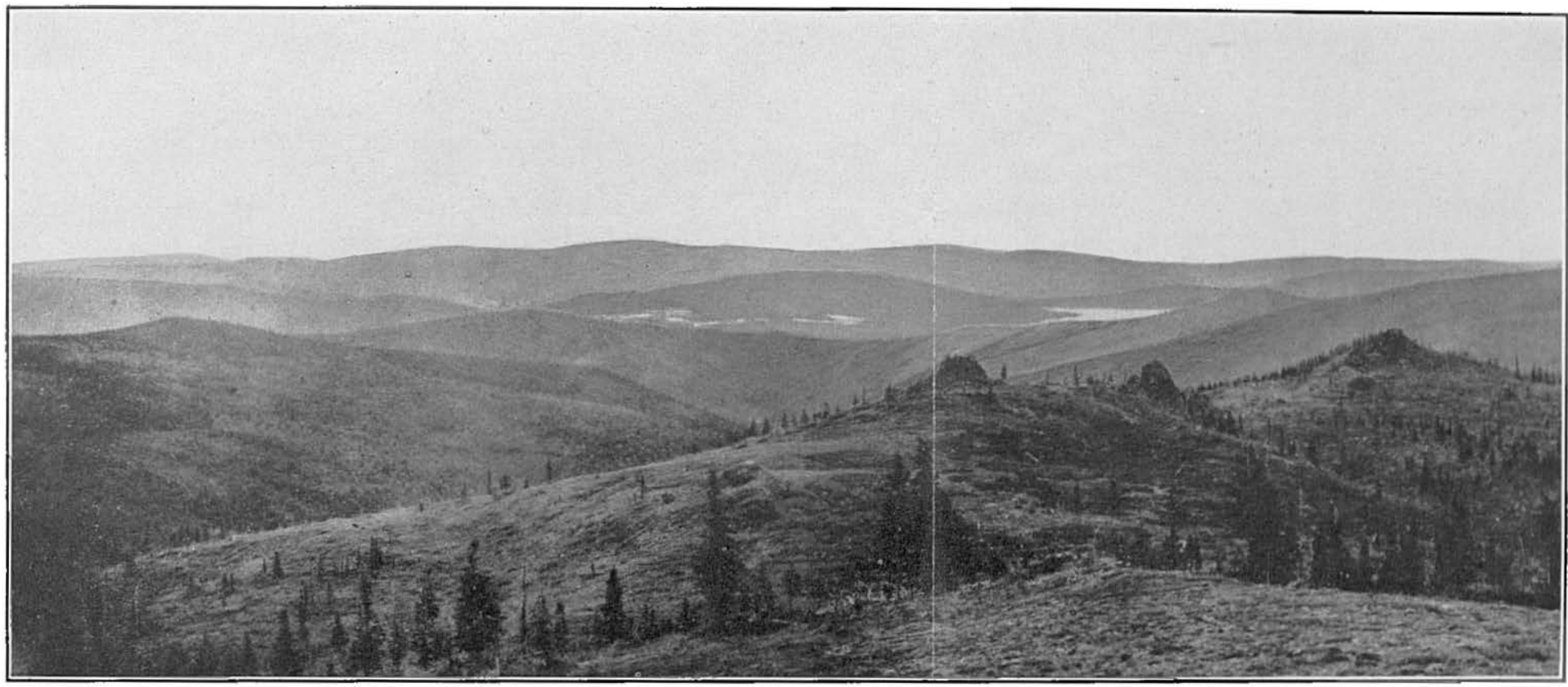

A. BROAD LOWER VALLEY OF GEORGE CREEK WHERE IT JOINS THE TANANA RIVER

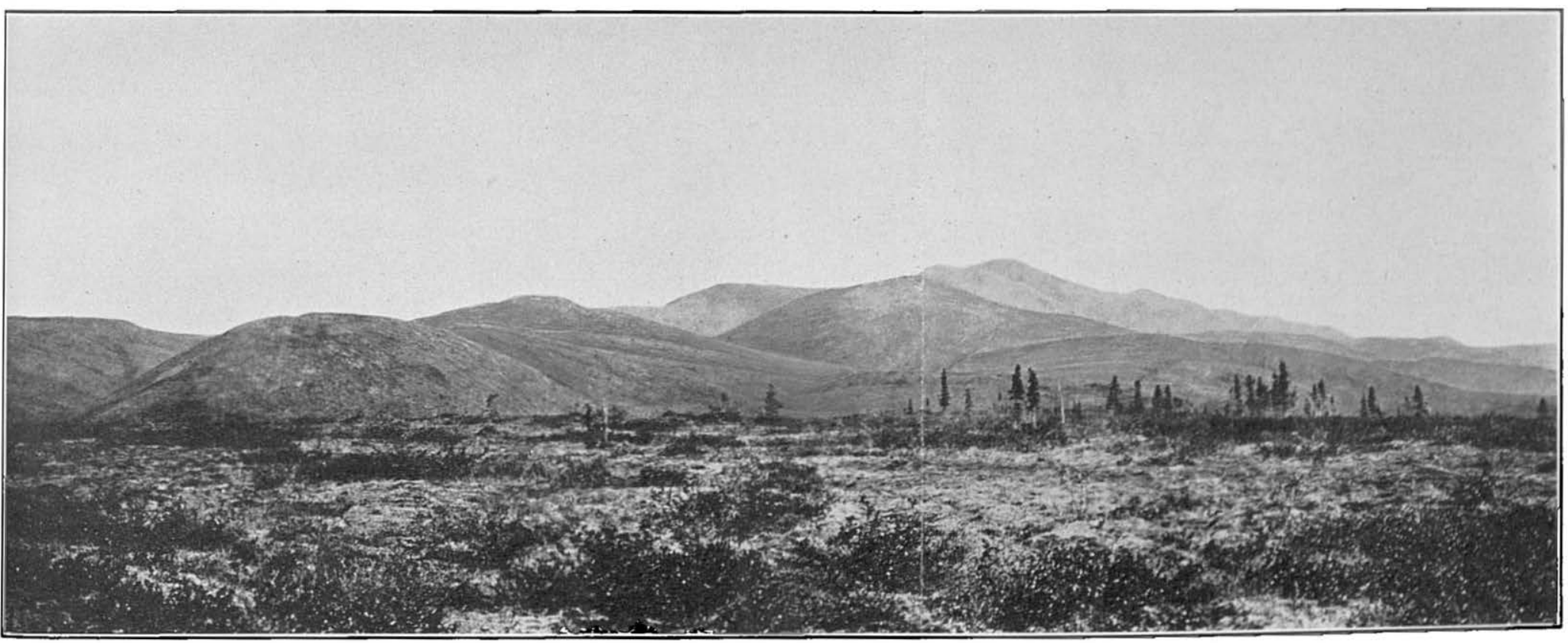

B. MOUNT FAIRPLAY FROM THE NORTHWEST AND THE MASSIF SURROUNDING IT 



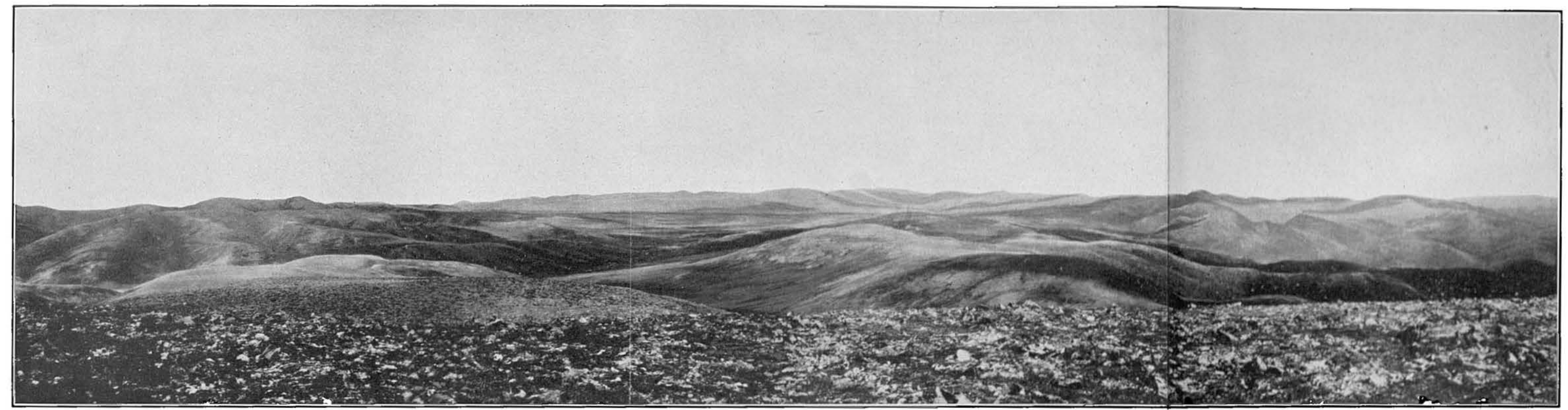

A. PANORAMIC VIEW LOOKING NORTHEAST FROM HEAD OF GEORGE CREEK

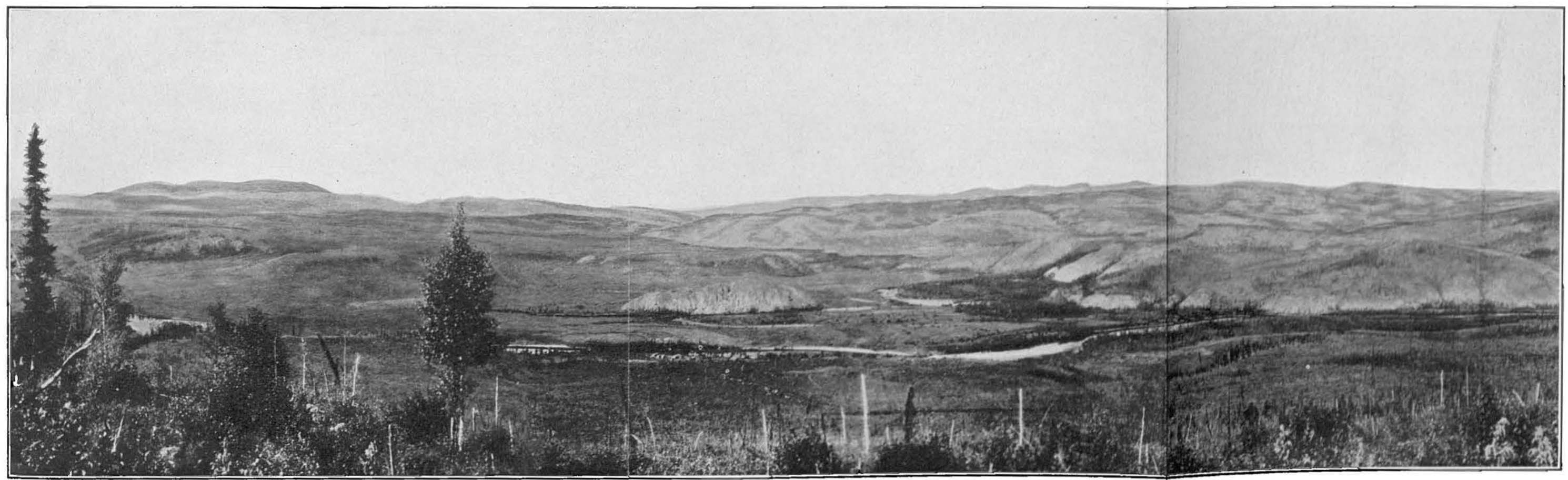

B. VALLEY OF MOSQUITO FORK, LOOKING UPSTREAM FROM CONFLUENCE WITH DENNISON FORK 



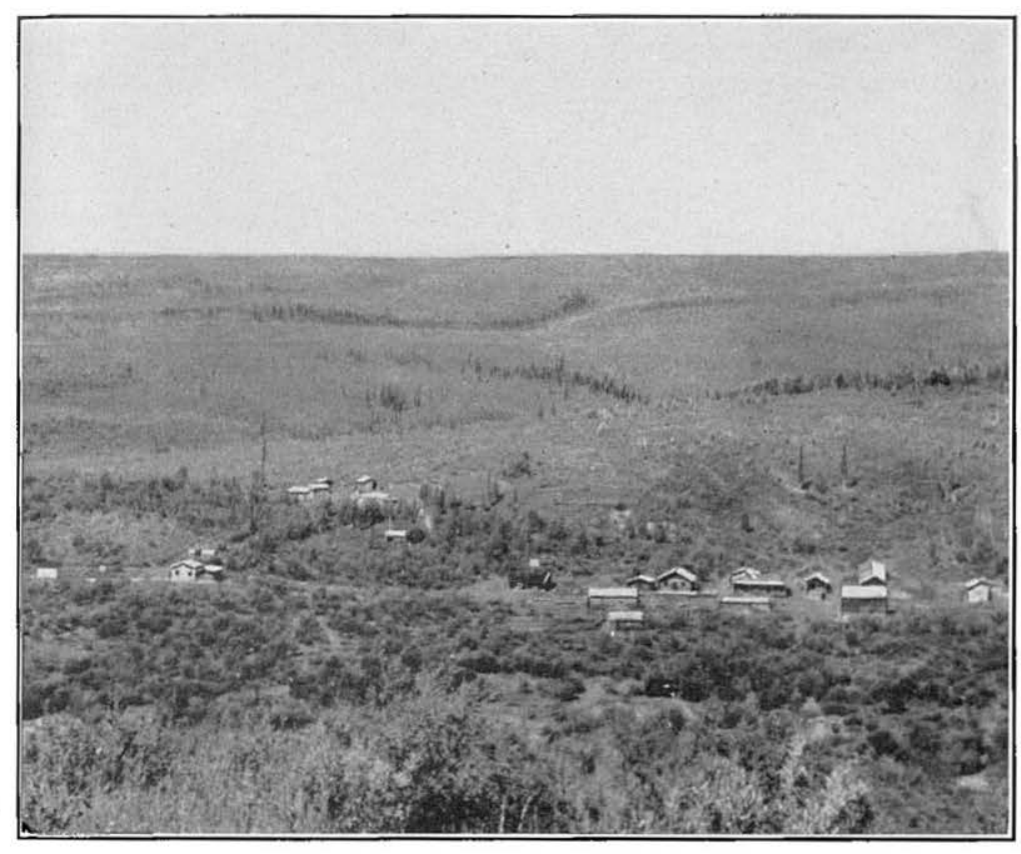

A. CHICKEN FROM THE EAST

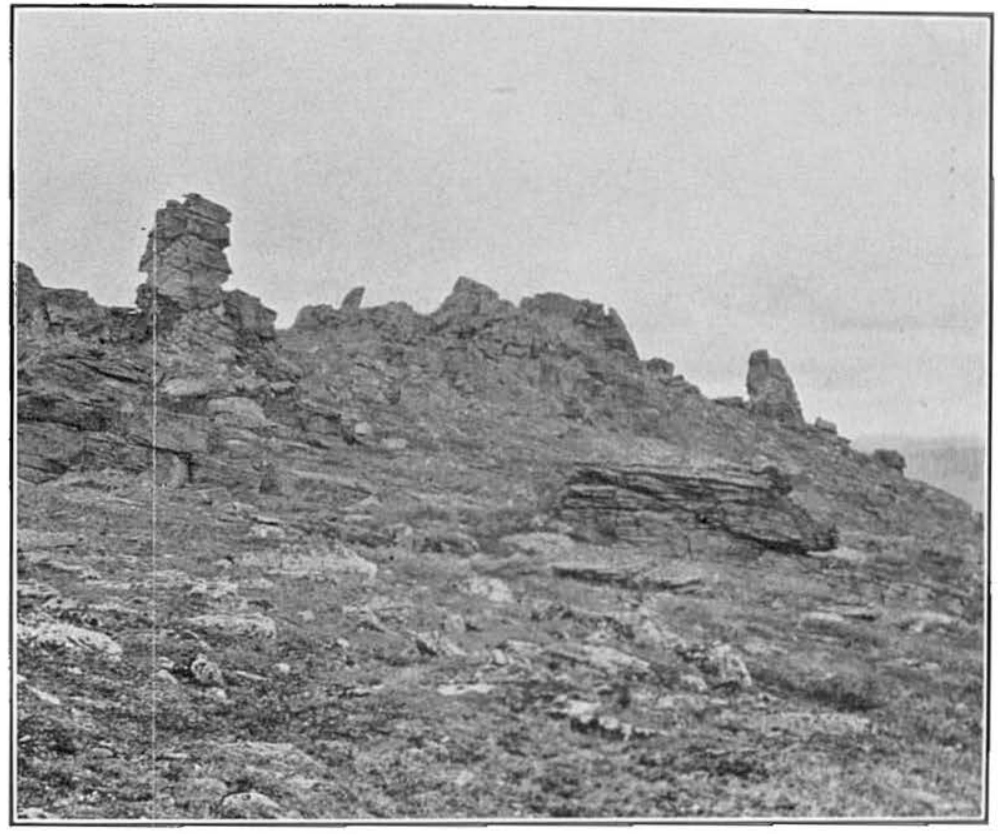

B. TYPICAL OUTCROP OF PELLY GNEISS ALONG RIDGE TOP' Shows monolithic type of weathering.

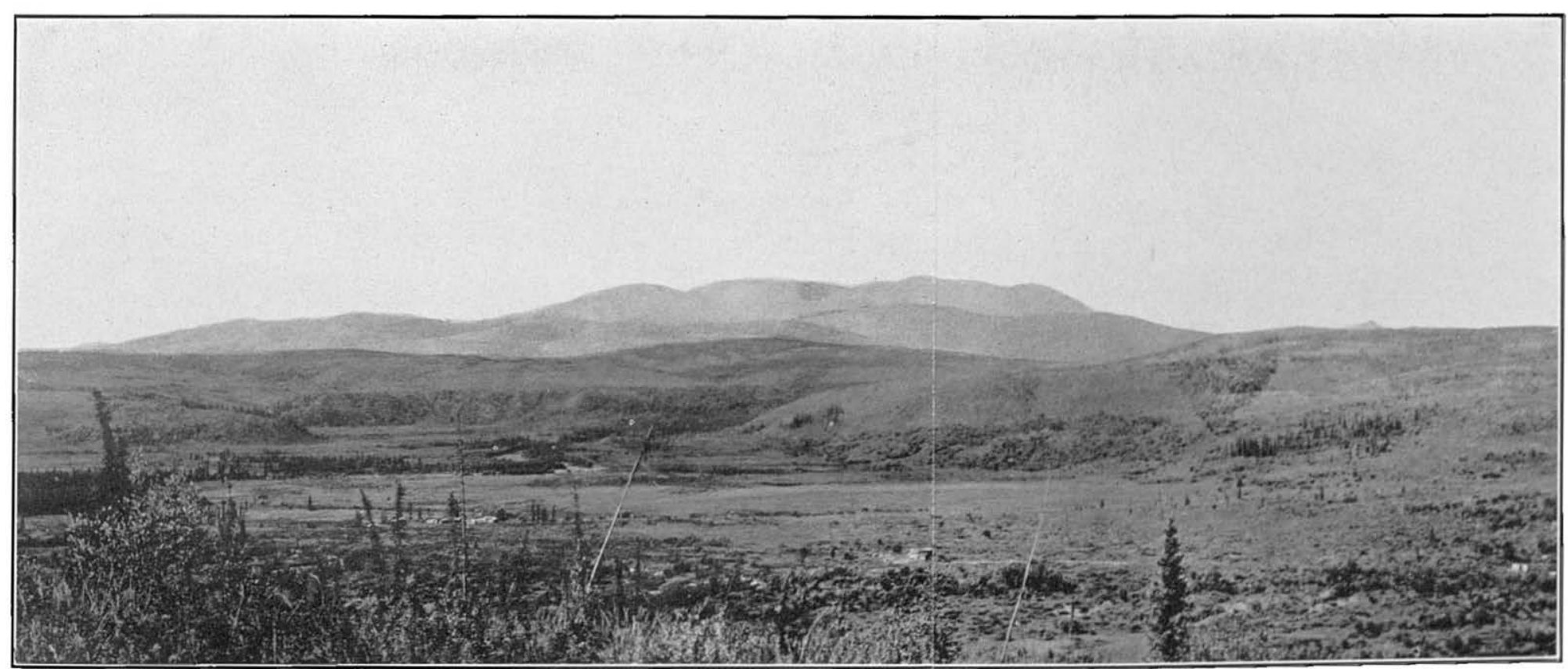

C. LOWER VALLEY OF CHICKEN CREEK AT ITS JUNCTION WITH MOSQUITO FORK Site of new airplane landing field in foreground; Taylor mountain in hackground. 



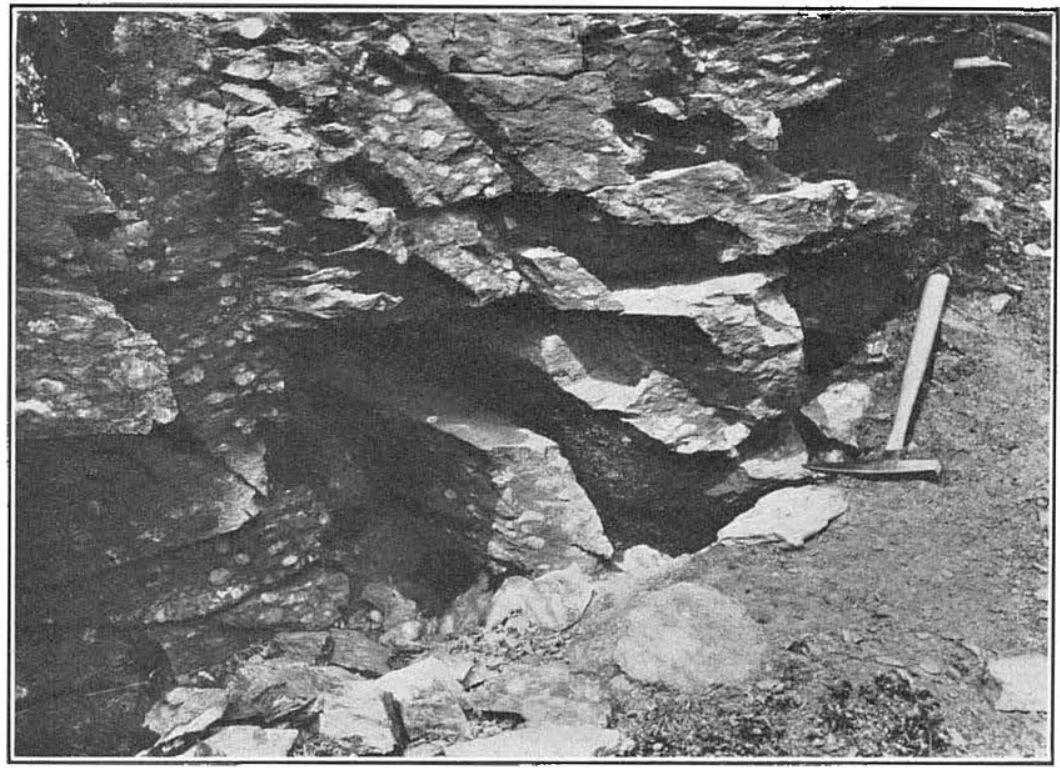

A. AUGEN GNEISS, A PHASE OF THE PELLY gNEISS

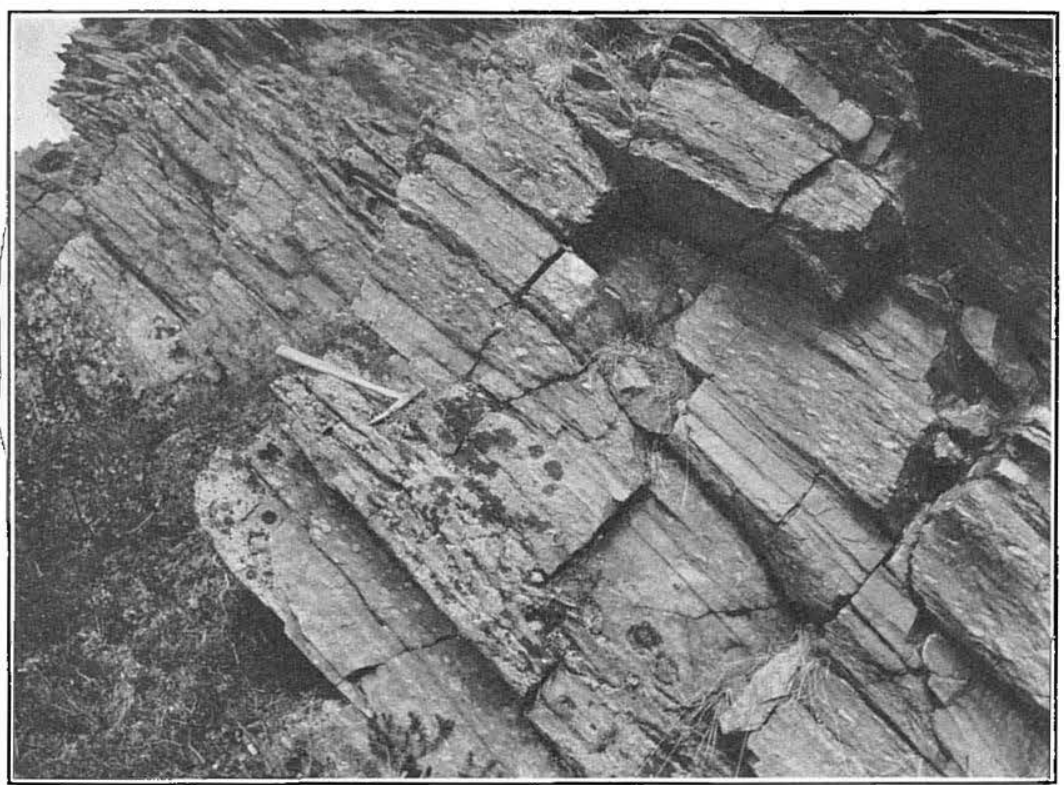

B. AUGEN GNEISS INTERLAMINATED WITH QUARTZITE SCHIST 


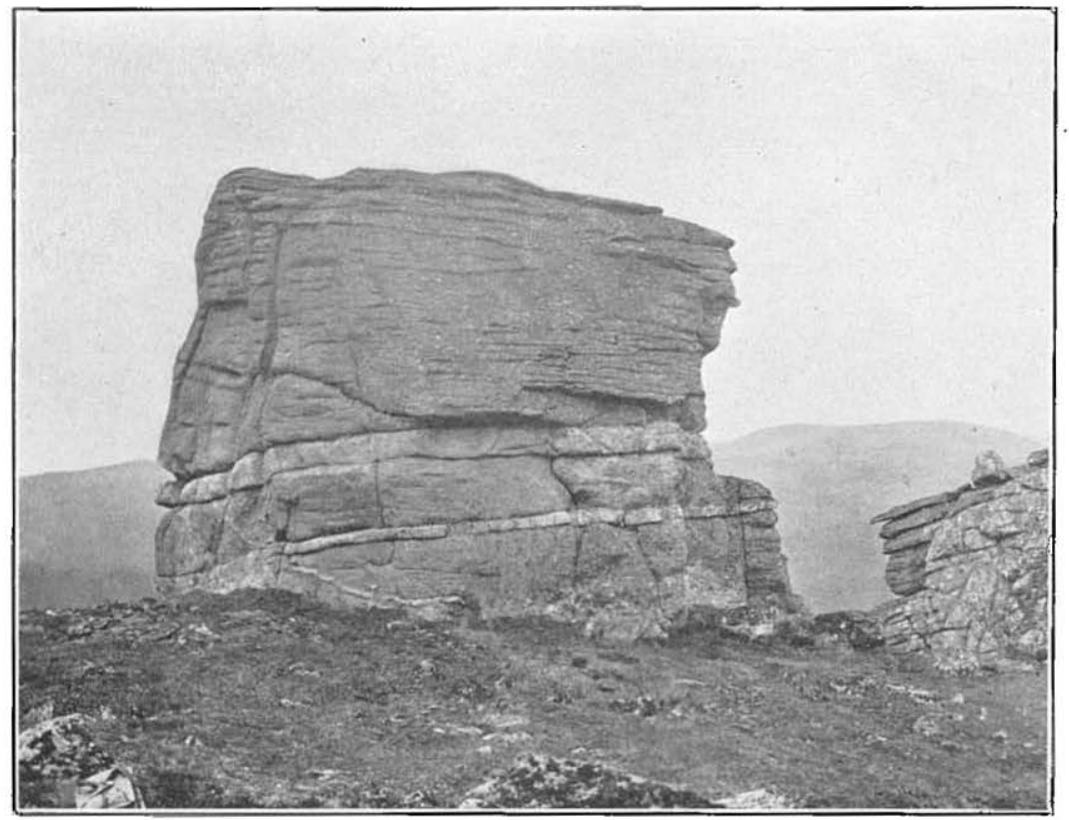

A. PELLY GNEISS INTRUDED BY MESOZOIC GRANITIC ROCKS

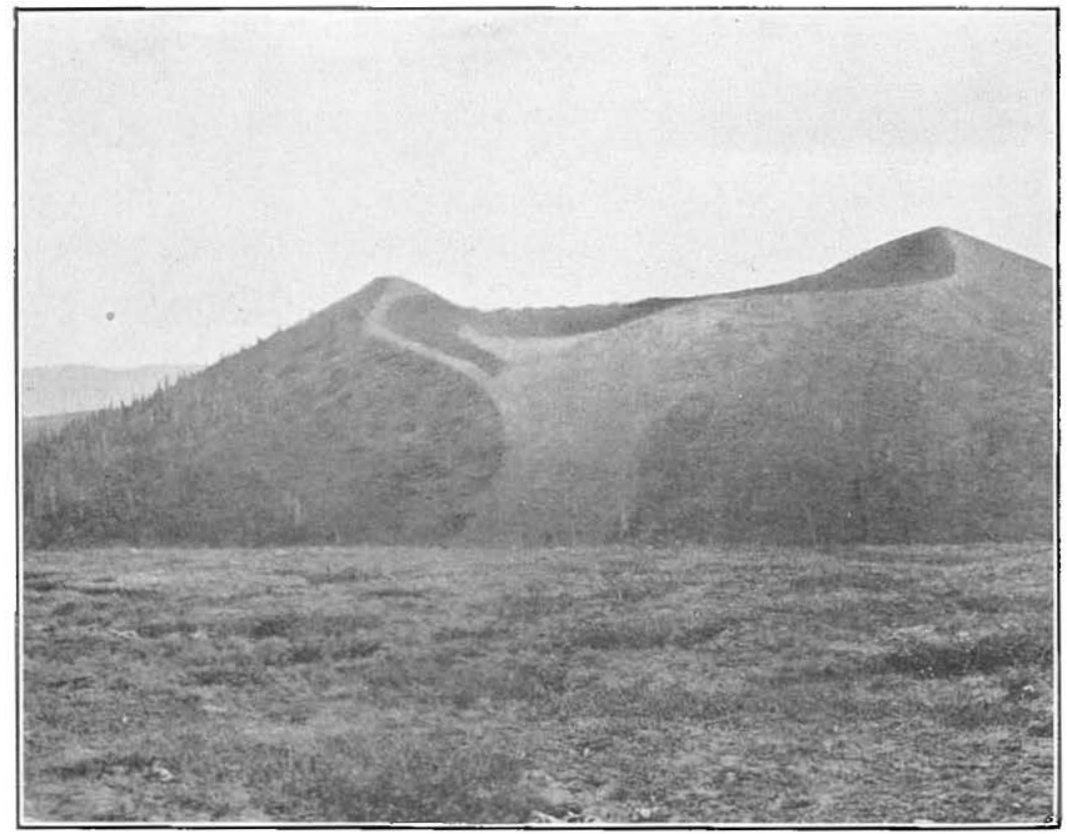

B. VOLCANIC CONE, EAST FOIK OF DENAISON FORK 
corners of the district, where unvisited areas of considerable: size intervene between the Tanana traverse of Brooks in 1899 and the writer's traverse in 1928. Also, the lack of areal traversing has doubtless resulted in the inclusion with the Birch Creek schist of small areas of Mesozoic and Tertiary igneous rocks, particularly in the eastern part of the district.

One large group of metamorphic igneous rocks, known in Yukon Territory as the Pelly gneiss, has in this report been mapped with the Birch Creek schist, because this area has not been worked in sufficient detail to map these rocks separately. These gneisses are particularly well developed at many localities in the eastern part of the Dennison Fork district, where they form a considerable part of the country rock. They weather at many places in such a manner as to produce isolated monoliths along the tops of otherwise smooth ridges. Such weathering is shown in Plates $6, B$, and $8, A$.

\section{IITHOTOGY AND STRUOTURE}

The Birch Creek schist and associated rocks have been described so thoroughly by Prindle ${ }^{b}$ in his reports on the Yukon-Tanana region that it seems unnecessary here to do more than summarize the general character of these rocks and to point out the present consensus of opinion regarding their classification, origin, and age.

One important difference in classification should be mentioned. Prindle's report on the Fortymile quadrangle ${ }^{7}$ contains the following statement: "Under the provisional designation of pre-Ordovician is included here a complex of crystalline rocks, some of which are definitely sedimentary and some of which are as definitely of igneous origin." The name Birch Creek schist was not, to be sure, definitely applied to the pre-Ordovician complex in that report, but it was subsequently applied to equivalent rocks in the Yukon-Tanana region, so that the designation Birch Creek schist came to be understood as including all the ancient metamorphic rocks of both sedimentary and igneous origin. By a recent decision of the committee on geologic names of the Geological Survey, the name Birch Creek schist is to be restricted to the pre-Cambrian metamorphic rocks of sedimentary origin. Hence, in this report, where the metamorphic rocks of igneous origin have not been separately mapped, the designation "Birch Creek schist and associated igneous rocks" is used.

- P'rindle, L. M., The gold placers of the Fortymile, Birch Creek, and Fairbanks regions, Alaska : U. S. Geol. Survey Bull. 251, pp. 27-31, 1905 ; The Fortymlle quadrangle, YukonTanana region, Alaska : U. S. Geol. Survey Bull. 375, pp. 16-18, 1909 ; A geologic reconnaissance of the Fairbanks quadrangle, Alaska: U. S. Geol. Survey Bull. 525, pp. 35-36, $60-66,1913$; A geologic reconnaissapce of the Circle quadrangle, Alaska: U. S. Geol. Survey Bull. 538, pp. 23-25, 1913.

7 Prindle, L. M., op. cit. (Bull. 375), p. 16.

$67638-31-2$ 
These metamorphic rocks of sedimentary origin consist principally of quartzite, quartzite schist, quartz-mica schist, and mica schist, with a minor proportion of carbonaceous and calcareous schist and crystalline limestone. Most of these rocks are completely recrystallized, but in some of the more competent beds-for example, the quartzite-original detrital fabric and other evidences of sedimentary origin have been preserved. In general, however, these rocks are characterized by a foliated or laminated structure of secondary origin, and many of them by a distorted foliate or crenulated fabric.

The dominant minerals of these rocks are quartz and mica in varying proportions; the accessory minerals are feldspar, hydromicas, calcite, epidote, and iron oxides. The quartzites are massive rocks almost free of mica and under the microscope are seen to consist mainly of interlocking grains of quartz, much of which shows strain shadows under crossed nicol prisms. The mica schists are foliated rocks composed mainly of leaves of biotite and muscovite, with little quartz. All varieties between these two extreme rock types are found. Feldspathic quartz-mica schists also constitute a part of the sequence, and as these are partly of sedimentary origin and partly of igneous origin, their detailed mapping will constitute a difficult problem. Locally, where the rocks of the Birch Creek schist are in contact with masses of granitic rock, as in the Mosquito Fork area, magmatic material has been transferred to the schists, the result being the development of several varieties of contact-metamorphic minerals such as albite, staurolite, and garnet. The more massive rocks, such as quartzite and quartzite schist, are believed to be near the base of the Birch Creek schist, and it is a significant fact that such rocks are more prevalent in the Fortymile-Tanana district than the more micaceous varieties.

The most abundant metamorphic igneous rocks here mapped with the Birch Creek schist are those grouped under the name Pelly gneiss. These gneisses are typically light-colored rocks, having a secondary structure that ranges from the regularly laminated gneissoid to the contorted schistose fabric-that is, texturally, all variations may be seen from rather massive gneiss to a feldspathic quartzmica schist. The more typical gneissoid type is characterized by many augen, usually of feldspar, rarely of quartz, which range from 3 inches in diameter downward to microscopic dimensions. (See pl. $7, A$.) Where the augen gneiss is highly developed, as on the ridge south of Liberty Creek, feldspar augen are at places so thickly crowded together that it is difficult to obtain a specimen of the matrix. One hundred such augen, many of them as large as an inch in diameter, were counted in 1 square foot of a large slab of rock. Many of these are elongated in the ratio of 1 to $1 \frac{1}{2}$. 
The Pelly gneiss consists mainly of granitic rocks but includes darker varieties of monzonitic, dioritic, and even gabbroic character. Texturally also it grades into the feldspathic quartz-mica schists, so that the Pelly gneiss and related rocks present difficult problems in petrogenesis and cartographic representation.

Under the microscope the range from originally granitic to gabbroic types is even more evident. Rocks that appear to be classifiable as originally granite, quartz monozonite, granodiorite, quartz diorite, and quartz gabbro have been recognized. In the granitic types quartz, orthoclase or microcline, albite, and mica seem to constitute the essential mineral components; the accessory minerals are apatite, zircon, garnet, and magnetite, and the secondary minerals quartz, sericite, several varieties of chlorite, epidote, calcite, and iron hydroxides. Of the micas, biotite is much more common than muscovite, but as these rocks veer toward feldspathic schist muscovite becomes more common than biotite. The monzonitic and dioritic types contain usually both orthoclase and soda-lime plagioclase in varying amounts, though in a few such rocks orthoclase is entirely absent. Green hornblende becomes the prominent mafic mineral in place of mica, and titanite and magnetite become more prominent among the accessory minerals. The quartz gabbroic types are closely related to the quartz diorites, in that hornblende, and not pyroxene, still constitutes the main dark mineral, although the plagioclase is sufficiently basic to render the designation quartz gabbro applicable.

The constant and locally high percentage of albite among the alkali feldspars of the granitic gneisses is perhaps the most interesting petrographic feature. In some specimens albite and orthoclase are present in a $1: 1$ ratio; in others a much smaller amount of albite occurs; and in some oligoclase rather than albite is present. The albite of these rocks appears to be of three rather different types. One is the albite that replaces orthoclase or plagioclase feldspar by the process commonly designated albitization. When orthoclase is replaced the secondary products are largely sericite and albite. When plagioclase is replaced the lime seems to be leached out, leaving a somewhat porous mass of albite, or more commonly oligoclase, with sericitic and kaolinic by-products. Evidence of this process is most easily seen in the granitic gneiss, where augen of orthoclase show in places rims of albite, and more rarely the augen are entirely replaced by a white granular mass of albite.

The second type of albite is, in the opinion of the writer, original magmatic material. Such albite is intergrown with quartz and orthoclase in a fabric that seems original, though the crystals may be crushed or elongated as a result of later deformation. Rarely graphic or perthitic intergrowths occur. Much of this albite is un- 
twinned and, as it is not associated with secondary products, requires close scrutiny for its recognition under the microscope.

The third type is really characteristic of the feldspathic schists. This is the familiar crystalloblastic albite that grows like ottrelite in the metamorphic rocks, with many inclusions of the other rockforming minerals.

Other metamorphic igneous rocks here mapped with the Birch Creek schist include amphibolite and hornblende, chlorite, epidote, and sericite schists of a variety of types. Such rocks, though of minor extent in this area, will sometime have to be distinguished from the Birch Creek schist and separately mapped.

The structure of the Birch Creek schist and related igneous rocks is very complex, probably more than ordinarily so in this district on account of the deformative effects of younger intrusive rocks. This regional trend is reflected in the general courses of the Dennison and Mosquito Forks within this area. The Tanana River apparently flows nearly at right angles to this structure and here at least does not appear to be related to the regional strike of the older rocks. Just east of the Dennison Fork, between Taylor Mountain and Liberty Creek, occurs an infolded area of Paleozoic rocks, which extend northward into the Fortymile quadrangle, and the elongation of this infolded area is about parallel to this regional trend of the cleavage-N. $15^{\circ} \mathrm{E}$. The prevailing dip of the cleavage of the Birch Creek schist and related rocks is $15^{\circ}-20^{\circ} \mathrm{E}$., but this attitude is by no means uniform. Some westward dips were recorded, and along the ridges south of Liberty Creek the cleavage of the Pelly gneiss is at places almost horizontal.

If the attitude of this cleavage had been induced principally by the intrusive rocks of this area, the relationship might be expected to appear along the edges of the larger granitic masses. In reality, however, the same general regional strike and dip of cleavage appears to prevail in the older rocks west of the Dennison Fork, where the intrusive rocks occur, as between the Dennison Fork and the boundary, where intrusive rocks are relatively scarce. The granitic rocks, therefore, are not believed to be the principal or even an important factor in the development of the present cleavage of these older rocks. On the other hand, the older Paleozoic rocks likewise have the same general structure as the Birch Creek schist and related rocks. It is therefore inferred that the principal cleavage at present observable in the Birch Creek schist and Pelly gneiss was developed prior to the injection of the granitic rocks and subsequent to the deposition of the older Paleozoic rocks. Plate 7, $B$, shows gneiss interlaminated with quartzite schist and the cleavage developed in both. The original structure of the Birch Creek schist and associated rocks, prior to the development of the present cleavage, may have 
been quitel at variance writh the present structure and is at best a matter of mere eonjecture.

\section{AGE AND CORRELATION}

The earliest geologic descriptions of the ancient metamorphic rocks of this region are found in the writings of Dawson and McConneli, based upon their joint explorations in northwestern Canada and Alaska during 1887 and 1888. Dawson originally divided the ancient rocks into two subdivisions, as follows:

1. An upper series of gray and blackish, often lustrous and sometimes more or less micaceous calc-schists and quartzites, including bed's of limestone of moderate thickness; often more or less dolomitic.

2. A lower series of greenish and gray schists, generally feldspathic or hornblendic but :often quartzose and including distinctly micaceous and talcose schists, with some; bands of limestone.

McConnell, who in addition to his work in Yukon Territory also traversed the Porcupine River and the Yukon from Fort Yukon upstream in 1888, likewise separated the crystalline rocks into two parts, as follows:

1. An upper series of sheared and altered quartzose schist, with which are associated greenish chlorite-bearing schists, lustrous mica schists, diabases, and serpentines. Interbedded with the schists are occasional bands of slate and crystalline limestone, broken at places by igneous intrusions.

2. A lower series consisting of a great thickness of well-foliated mica gneisses, alternating with mica and hornblende schists.

Although Cambrian fossils had not been found at that time north of British Columbia, both Dawson and McConnell regarded the oldest rocks of Yukon Territory and Alaska as pre-Cambrian. Later workers in Alaska, wishing to be conservative in their geologic statements, designated them successively pre-Devonian, pre-Silurian, and pre-Ordovician; but eventually, with the discovery of Cambrian faunas, the original designations of Dawson and McConnell were substantiated.

In 1891 an expedition in charge of Frederick Schwatka, with C. W. Hayes ${ }^{\theta}$ attached as geologist, entered British Columbia by way of the Taku River and thence traversed successively the upper Yukon, White, Nizina, and lower Copper Rivers. Hayes presented no complete geologic section, but his notes mention particularly a reddish porphyritic gneissoid granite east of the Coast Range in the Lake Ahklen country, which he regarded as Archean. This forma-

\footnotetext{
8 Dawson, G. M., Report on an exploration in the Yukon district, Northwest Territory, and adjacent portion of British Columbia: Canada Geol. Survey Ann. Rept., vol. 3, pp. $1-183$, 1888. McConnell, R. G., Report on an exploration in the Yukon and Mackenzie Basing, Northwest Territory : Canada Geol. Survey Ann. Rept., vol. 4, pp. 13D-14D, 1891.

- Hayes, C. W., Expedition through the Yukon district: Nat. Geog. Mag., vol. 4, pp. 117-159, 1892.
} 
tion is possibly correlative with the gneissoid rocks of McConnell's lower series, but Hayes may have included some of the Mesozoic granitic rocks.

In 1896 Spurr ${ }^{10}$ traversed the entire length of the Yukon, visiting also the Fortymile district, and in his report was published the first geologic section applicable particularly to Alaska. The metamorphic rocks were divided by Spurr into three parts-an upper series, called the "Fortymile series," consisting of intercalated marble and quartzite, with hornblendic, micaceous, garnetiferous, and graphitic schists; a lower series, called the Birch Creek "series," composed mainly of quartzite, quartzite schist, and quartz-mica schist, with a minor proportion of schists of igneous origin; and a so-called basal granite, or granite gneiss, which Spurr, like Dawson, McConnell, and Hayes, believed to be the geologic basement of the region.

In 1898, two years after Spurr's work, Brooks ${ }^{11}$ made a trip from Skagway to Tanana by way of White Pass, the upper Yukon, and the White and Tanana Rivers. Brooks divided the ancient crystalline rocks into two parts, to the upper of which two names were applied, because these rocks occurred at widely separated localities and could not be correlated. One of these was the "Nasina series," consisting of a variety of schistose rocks, mainly of clastic origin, and some limestone. The type locality for the "Nasina series" was along the lower White River. The other series, called the "Tanana schists," crops out in three areas along the Tanana River and consists dominantly of gneissoid and schistose rocks, mainly of micaceous, calcareous, and graphitic schists. The lower division was termed the "Gneissic series" and, as the name indicates, consists dominantly of gneissoid and schistose rocks, mainly of granitic origin. Brooks, though he followed cartographically the interpretation of Dawson, McConnell, Hayes, and Spurr, was the first to question seriously the basal nature and Archean age of this gneiss.

In 1899 Brooks ${ }^{12}$ made another trip from Lymn Canal to Eagle, paralleling roughly on the southwest his trip of the preceding year, by way of the Klehini River, Lake Kluane, the headwaters of the White and Nabesna Rivers, and the Tetling, Ladue, and Fortymile Rivers. In the report describing the work of this expedition Brooks used the name " Kotlo series" to designate all the metamorphic rocks of dominantly sedimentary origin, which he correlated with the "Fortymile" and Birch Creek "series" and with the "Nasina series"

${ }^{20}$ Spurr, J. E., Geology of the Yukon gold district, Alaska : U. S. Geol. Survey Eighteenth Ann. Rept., pt. 3, pp. 87-392, 1898.

${ }^{11}$ Brooks, A. H., A reconnaissance in the Tanana and White River basins, A!aska, in 1898 : U. S. Geol. Surrey Twentieth Ann. Rept., pt. 7, pp. 431-509, 1900.

${ }_{12}$ Brooks, A. H., A reconnaissance from Fyramid Harbor to Eagle City, Alask., including a deseription of the copper deposits of the upper White and Tanana River: : IJ. S. Geol. Survey Twenty-first Ann. Rept., pt. 2, pp. 331-391, 1900. 
and the "Tanana schists." The age of the "Kotlo series" was given as lower Paleozoic and pre-Cambrian. He also separated the "Gneissic series," as before, but included with the ancient gneissic rocks, for cartographic purposes, many of the massive, nonmetamorphic granitic rocks of much later origin, particularly in the Fortymile and Ladue River Basins.

In the meanwhile, in 1899, McConnell ${ }^{13}$ had begun his semidetailed geologic studies in the Klondike gold fields, and in 1905 the results of this work up to 1903 were published. McConnell's geologic map, published on a scale of 2 miles to the inch, represents the first successful attempt to subdivide the old schistose rocks into well-defined, mappable units, based upon the origin and relative age of the several formations. This section, because it provides the foundation for present pre-Cambrian subdivision and nomenclature in Yukon Territory and Alaska, is given in full herewith:

1. Klondike series :

(a) Sericite and chlorite schists, derived from the alteration of acidic and basic porphyritic igneous rocks.

(b) Pelly gneiss, derived from the alteration of granite porphyry and quartz porphyry.

2. Moosehide group: Altered diabase, passing at some localities into serpentine.

3. Nasina series: Quartzite, quartzite schist, and quartz-mica schist, with some bands of chlorite and actinolite schist and crystalline limestone.

In this classification the term "Nasina series," proposed by Brooks, was retained and was restricted to the ancient crystalline rocks dominantly of sedimentary origin; the igneous members of the metamorphic complex were separately mapped. The term Pelly gneiss was here used for the first time to designate the rocks previously described by McConnell, Hayes, and Sjurr as fundamental gneisses. These rocks were also described by Brooks, but nowhere in Brooks's writings prior to McConnell's Klondike report has the writer been able to discover the designation Pelly gneiss. Perhaps the term was proposed by Brooks in correspondence with McConnell, who accepted it. In any event, Pelly gneiss is an appropriate name for these rocks. McConnell also recognized that the Klondike "series," of which he considered the Pelly gneiss to form a part, is in general of later origin than the metamorphosed clastic rocks, represented by the "Nasina series." Finally, the two subdivisions of the Klondike "series" were believed to be of much the same age and magmatic origin, the Pelly gneiss representing the deep-seated intrusive rocks, and the sericite schist the surficial phases of the same magma.

\footnotetext{
${ }^{18}$ McConnell, R. G., Report on the Klondike gold flelds : Canada Geol. Survey Ann. Rept.
} vol. 14 , pp. $5 \mathrm{~B}-71 \mathrm{~B}, 1905$. 
From 1903 to 1911 the study of the ancient crystalline rocks was continued by L. M. Prindle, in the Yukon-Tanana region of Alaska. Prindle published numerous reports, of which three ${ }^{14}$ may be taken as typical of the growth of knowledge regarding these older metamorphic rocks. In the first of these three reports the preexisting series and group names were ignored, and all the rocks corresponding to the "Nasina" and Klondike "series" and the Pelly gneiss were grouped under the designation pre-Ordovician rocks and described as consisting of quartzite, quartzite schist, calcareous quartzite schist, quartz-biotite schist, garnetiferous mica schist, hornblende schist, carbonaceous schist, crystalline limestone, biotite gneiss, hornblendeplagioclase gneiss, and biotite augen gneiss.

In his Fairbanks and Circle reports Prindle, following the usage proposed by Brooks, ${ }^{15}$ changed Spurr's name Birch Creek "series" to Birch Creek schist but used this name to designate the preOrdovician metamorphic rocks of this region, regardless of their character and origin, thus including metamorphic igneous rocks, such as the Klondike "series" and the Pelly gneiss. In view of the specific use to which the term "Nasina" had been applied by McConnell, the selection of a different term was perhaps justified, if a group term for all the pre-Ordovician metamorphic rocks was necessary. The term Birch Creek "series," however, had been most loosely defined by Spurr, and the new term Birch Creek schist had perforce to be expanded to include not only the original Birch Creek "series" but also some undetermined part of Spurr's "Fortymile series," which was even more loosely defined; moreover, the term "Fortymile series" was never used by any geologist subsequent to Spurr. In view of these facts and of the confusion likely to result from the use of the term Birch Creek, it would have been better at that time to use some other group name for the crystalline rocks, as was later done by Cairnes. However, the term Birch Creek has now become so deeply rooted in geologic literature, particularly in the Alaskan literature, that its continued use in some form or other is almost necessary.

More or less concomitantly with Prindle's work in the YukonTanana region, Brooks, ${ }^{16}$ Prindle, ${ }^{16}$ and Capps ${ }^{17}$ also studied these crystalline rocks south of the Tanana, along the north flank of the

\footnotetext{
14 Prindle, L. M., The Fortymile quadrangle, Yukon-Tanana region, Alaska: U. S. Geol. Survey Bull. 375, 1909; A geologic reconnaissance of the Fairbanks quadrangle, Alaska: U. S. Geol. Survey Bull. 525, 1913; A geologic reconnaissance of the Circle quadrangle, Alaska: U. S. Geol. Survey Bull. 538, 1913.

is Brooks, A. H., The Mount McKinley region, Alaska: U. S. Geol. Survey Prof. Paper 70 , pp. $59,60,1911$.

${ }^{16}$ Brooks, A. H., The Mount McKinley region, Alaska, with descriptions of the igneous rocks and of the Bonnifleld and Kantishna districts, by L. M. Prindle: U. S. Geol. Survey Prof. Paper 70, 1911.

${ }^{17}$ Capps, S. R., The Bonnifield region, Alaska: U. S. Geol. Survey Bull. 501, 1912.
} 
Alaska Range. The general result of these studies was the grouping of all the metamorphic rocks, both of sedimentary and igneous origin, under the general heading Birch Creek schist, with an age assignment of pre-Ordovician. One very significant fact which resulted from this work was the recognition and differentiation of a group of augen gneisses and metamorphosed igneous schists, to which the name Totatlanika schist was later applied by Capps. The age of the Totatlanika, however, was not determined beyond the fact that it was younger than the Birch Creek schist and older than Carboniferous.

Mention should also be made of the geologic work of Cairnes ${ }^{18}$ during 1909 and 1910 in the Wheaton and Atlin districts. The metamorphic rocks of both these districts, known as the Mount Stevens group, were classified in the Atlin report as lower Paleozoic. But the significant statement here appeared for the first time that the gneisses of the Atlin district seem to correspond with the Pelly gneiss, which is possibly of early Paleozoic age.

During 1911 and 1912 a geologic study of the international boundary between the Yukon and Porcupine Rivers was made by Cairnes, ${ }^{10}$ in connection with the international boundary survey. In this work Cairnes discovered Cambrian fossils, and, although these fossils were Upper Cambrian, he nevertheless felt justified, from his stratigraphic section, in referring the underlying metamorphic rocks to the pre-Cambrian. Being unable, however, to discriminate along the boundary the subdivisions of the pre-Cambrian proposed by McCon. nell in the Klondike district, he proposed a new name, Yukon group " to include all these older metamorphosed, schistose and gneissoid rocks of both sedimentary and igneous origin." This term, it will be noted, is the exact equivalent of the Birch Creek schist as redefined by Brooks and Prindle in 1902.

Similarly in 1913 Cairnes ${ }^{20}$ again used the term "Yukon group" to designate the mica schist, quartz-mica schist, quartzite schist, schistose quartzite, and schistose amphibolite of the upper White River district, and referred these rocks questionably to the preCambrian, with no special reference to the Pelly gneiss. Again, in 1916 he used the term Yukon group in the same sense ${ }^{21}$ but reverted to the original idea that the Pelly gneiss was an integral part of this pre-Cambrian sequence.

\footnotetext{
28 Cairnes, D. D., The Wheaton district, Yukon Territory : Canada Geol. Survey Mem. 31, 1912 ; Portions of the Atlin district, British Columbia: Canada Geol. Survey Mem. 37, 1913.

${ }^{10}$ Cairnes, D. D., The Yukon-Alaska international boundary between Porcupine and Yukon Rivers: Canada Geol. Survey Mem. 67, 1914.

${ }^{20}$ Cairnes, D. D., The upper White River district, Yukon Territory : Canada Geol. Survey Mem. 50, 1915.

n Cairnes, D. D., The Klotassin area, Yukon Territorq: Canada Geol. Survey Summary Rept. for 1916, p. 27, 1917.
} 
The next contribution to pre-Cambrian classification and nomenclature in Alaska and Yukon Territory was a paper by Cockfield ${ }^{22}$ embodying the results of his semidetailed studies, during 1917, in a relatively small area in the Sixtymile and Ladue River Valleys, adjoining the international boundary. Cockfield attempted the cartographic separation of the Yukon group into four members, and even if the field differentiations are difficult to follow consistently the information conveyed by this effort more than compensates for any imperfections of mapping. His section is as follows:

1. Granite gneiss.

2. Amphibolites.

3. Sericitic and chloritic schists, mainly of igneous origin.

4. Nasina series, at the base of the section, consisting of quartzite, quartz. mica schists, mica schists, sheared conglomerate, graphite schists, and crystalline limestone.

The granite gneiss is correlated with the Pelly gneiss, but it is not made a part of the Klondike "series," where McConnell placed it, but is considered to be intrusive into and therefore later than the Klondike "series." The amphibolites of division 2 are in part of igneous origin and in part of sedimentary origin and are probably for the most part younger than the rocks of the "Nasina series" but definitely older than the gneiss. Their age relation to the sericite and chlorite schists, however, is undetermined. The "Nasina series" comprises the oldest metamorphic rocks of the region, and these are considered to be dominantly of sedimentary origin.

Additional data bearing on the age of the Birch Creek schist are contained in a recent report. ${ }^{23}$ Fossils that were found in the, early Paleozoic rocks along the Yukon near Eagle have been determined by C. E. Resser, of the United States National Museum, as early Middle Cambrian. Other rocks that underlie the fossiliferous beds and overlie the Birch Creek schist make even more certain the conclusion reached by Cairnes that the Birch Creek schist is definitely of pre-Cambrian age.

The United States Geological Survey now restricts the name Birch Creek schist to the pre-Cambrian metamorphic rocks of sedimentary origin. By this usage the term Birch Creek schist becomes the strict analog of the Canadian term "Nasina series." Therefore, in the future, where it is necessary to map collectively all the pre-Cambrian metamorphic rocks, of both sedimentary and igneous origin, two alternatives present themselves. A group name, such as the Canadian term Yukon group, might be used to designate all the

\footnotetext{
m Cockfleld, W. E., Sixtymile and Ladue Rivers area, Yukon Territory: Canada Geol. Surrey Mem. 123, 1921.

as Mertle, J. B., fr., Geology of the Eagle-Circle district, Alaska : U. S. Geol. Survey Bull. 816, pp. 17-20, 1930.
} 
pre-Cambrian rocks, or the geologic explanation may read "Birch Creek schist and associated igneous ,rocks," or some similar title. In view of the long association of the expression Birch Creek schist with the ancient crystalline rocks in Alaska, the latter usage appears preferable. As no attempt has yet been made in the Yukon-Tanana region to map separately the metamorphic igneous rocks of the preCambrian sequence, no system, series, or formational names other than Birch Creek schist are officially recognized.

This restriction of the term Birch Creek schist to the pre-Cambrian metamorphic rocks of sedimentary origin leaves open the question of the age of the associated metamorphic rocks of igneous origin. Of such rocks the granitic gneiss, called by the Geological Survey of Canada the Pelly gneiss, is the most conspicuous and most easily identified in the Dennison Fork district. This gneiss is known definitely to intrude some of the more massive rocks of the Birch Creek schist, such as the quartzite and quartzite schist, which, however, are believed to belong well down in the sequence of these ancient rocks. Also it is known to be intruded by the Mesozoic granitic rocks, as shown in Plate $8, A$. But it can not be proved from the field evidence alone that the gneiss is younger than all of the Birch Creek schist, though such may in fact be true. The possible correlation of the Pelly gneiss with the Totatlanika schist has already been suggested. Against this correlation, however, is the fact that the Totatlanika schist appears to consist mainly of metamorphosed rhyolite porphyry, of surficial origin. As the Totatlanika schist also appęars to be definitely younger than the Birch Creek schist, this correlation should not at present be made. If, however, the Totatlanika schist is subsequently traced eastward into Yukon Territory, its relation to the Klondike schist and Pelly gneiss may be discovered. At present all that may definitely be said of the age of the Pelly gneiss is that it is younger than the oldest rocks of the Birch Creek schist and may possibly be as young as early Paleozoic.

\section{UNDIFFERENTIATED PALEOZOIC ROCKS}

\section{DISTRIBUTION}

Two areas of metamorphosed Paleozoic rocks are known within the Dennison Fork district, and other areas of similar rocks may also be present. One of the known areas is along the east side of the Dennison Fork, at the north edge of the district, and continues northward into the Fortymile quadrangle, where it forms the bedrock on the South Fork of the Fortymile River downstream from the mouth cf the Dennison Fork. The other area is along the northeast side of the Tanana River, mainly in the basin of lower Gardiner Creek. 
This area, which was not visited by the writer, was originally mapped by Brooks ${ }^{24}$ as part of his "Tanana schists."

\section{IITHOLOGY AND STRUCTURE}

The rocks along the Dennison Fork are a part of the sequence that has been examined by Prindle ${ }^{25}$ in the Fortymile quadrangle. They consist, according to Prindle, of green and black phyllite, cherty slate, greenstone, serpentine, quartzite, and limestone. The greenstones are particularly noticeable where outcrops are poor.

The rocks along the northeast side of the Tanana River above the Nabesna are described by Brooks ${ }^{28}$ as dominantly calcareous schist, interbedded with phyllite. The calcareous schist is gray and in places finely banded, and in thin section it shows clastic grains of quartz, orthoclase, and plagioclase, both rounded and angular, cemented by calcite. The presence of so much feldspathic material in these schists suggested to Brooks that they may have been derived in part from the disintegration of his "Gneissic series," now known as the Pelly gneiss.

Practically nothing is known of the details of structure in these rocks. In the Dennison Fork area, as previously mentioned, they appear to trend $\mathrm{N} .15^{\circ} \mathrm{E}$., roughly parallel to the cleavage of the Birch Creek and associated gneiss. These rocks are clearly less metamorphosed than the pre-Cambrian rocks. It is therefore believed that these undifferentiated Paleozoic rocks were principally deformed at the time when the latest cleavage was developed in the rocks of the Birch Creek schist, although the Birch Creek may have been repeatedly metamorphosed prior to that time.

\section{AGE AND CORRELATION}

No fossils have been found in these rocks within the Dennison Fork district, but just to the north, in the Fortymile quadrangle, on the Fortymile River a quarter of a mile below the mouth of Napoleon Creek (locality 7AP82), Prindle found some organic remains in them. According to E. M. Kindle, these fossils consist of crinoid stems of little diagnostic value, but nevertheless they serve to show the Paleozoic age of these rocks and to separate them distinctly from the more metamorphosed Birch Creek schist. Crinoids are not commonly found in rocks older than Ordovician, and therefore such remains, considered without reference to any other fossils, justify only the designation post-Cambrian for these rocks. Another collec-

\footnotetext{
2* Brooks, A. H., A reconnaissunce in the Tanana and White River basins, Alaska: U. S. Geol. Survey Twentieth Ann. Rept., pt. 7, pp. 468-469, 1900.

\$ Prindle, L. M., The Fortymile quadrangle, Alaska : U. S. Geol. Survey Bull. 375, pp. 18-19, 1909.

20 Brooks, A. H., op. cit., p. 468.
} 
tion of fossils was made by. Prindle from rocks of the same general character in the Circle quadrangle, about 40 miles west of Eagle (locality 4AP446), and these were doubtfully referred by Kindle to Zaphrentis? sp., thus suggesting a Silurian or Devonian age. It is very unlikely that any Carboniferous rocks are included in this group, because the marine Carboniferous rocks of this region are highly fossiliferous, and metamorphism has not been sufficiently intense in these rocks to obliterate fossils. They may be in part of Devonian age, but if so they are more metamorphosed than most of the Devonian rocks of this region. The included greenstones are more likely to be of Devonian age than the altered sediments. The sedimentary rocks of this group may well be in part or altogether Silurian. The only designation at present justified, however, is early Paleozoic.

\section{WELLESLEY FORMATION}

\section{DISTRIBUTION}

Rocks mapped by Brooks ${ }^{27}$ as the Wellesley formation are found in the southeast corner of the Dennison Fork district, south of Mirror Creek, and also west of Chisana River.

\section{IITHOLOGY AND STRUOTURE}

These rocks were not seen by the writer, and the following quotation from Brooks's report gives all the available information regarding them:

This formation can be roughly divided into two parts, the lower consisting of a coarse massive conglomerate interlarded with a few beds of clay slate, while the upper part consists almost entirely of clay slate. * * Some dikes were observed cutting the slate; but these are of secondary importance, and the series consists essentially of sedimentary rocks. *** The conglomerate is very massive and seems to have been but little affected by the deformation which has locally considerably altered the associated slates. The pebbles of the conglomerate vary in size from a fraction of an inch to 18 inches in diameter. The cement is siliceous and ferruginous, giving a reddish color after weathering. The pebbles are very largely identical with the more massive phases of the greenstone schist series. It is a striking fact that while the pebbles have been very largely derived from the greenstone, they are for the most part massive. The deformation, therefore, which has altered the greenstones must have taken place since the deposition of the conglomerate and seems to have affected the conglomerate itself comparatively little. Massive quartzite pebbles whose derivation is unknown were also found in the conglomerate. The clay slate is a blue rock having usually an even fracture and frequently containing a considerable percentage of carbonaceous matter. Locally the slate is altered to a phyllite containing considerable sericite. This is especially noticeable along the lines of faulting found in the Mirror Oreek Valley. * * The slates where altered frequently contain quartz veins.

${ }^{27}$ Brooks, A. H., op. cit., maps 24, 25, pp. 470-472. 
The Wellesley formation overlies the greenstone schists unconformably. Its strikes are approximately northwest and southeast, and it occurs as a series of closed folds, which are more or less faulted and are overturned to the west. * * * Along the northern margin of the mass considerable faulting has taken place, and it dips directly toward the greenstone.

The probable minimum thickness of the Wellesley formation is given by Brooks as between 1,000 and 2,000 feet, although no exact measurements were made.

\section{AGE AND CORRELATION}

One collection of fossils was made by Brooks from the Wellesley formation, at a point about 15 miles southeast of the mouth of Mirror Creek, in the valley of the Snag River. The report of Charles Schuchert ${ }^{28}$ on the fossils is as follows:

The most abundant species present is a small Nucula having the general appearance of Nucula leda Hall and Whitfleld and $N$. corbuliformis Hall, of the Middle Devonian. On the other hand, since Nuculas are generally present in faunas of the Devonian and Carboniferous, it is at present impossible to say to which of these two systems the fossils in question belong. That the age of this Nucula can not be younger than the Carboniferous is proved by the fact that associated with them is a fragment of a thoracic segment (a pleura) of a trilobite. Nuculoid genera are known throughout the geologic column, beginning with the Ordovician system, but the aspect of the Tanana species is more that of late than early Paleozoic times.

A closely coiled Bellerophon is also present, but since the only specimen is very small and shows no surface ornamentation, it has no particular stratigraphic value.

At the time when this collection was made few Paleozoic fossils had been collected in Alaska, and therefore it was not possible to compare these fossils with other Alaskan faunas of Devonian or Carboniferous age. At present it may be stated that Nucula and Bellerophon have not been found in the Middle Devonian rocks of the Chisana-White River and Broad Pass districts to the south and southwest; nor are these genera known either in the Middle Devonian faunas of the Porcupine and upper Yukon Rivers or in the Upper Devonian fauna of northern Alaska. On the other hand, both these genera are well known in the Carboniferous of interior and northern' Alaska, particularly in rocks of Mississippian age. Although these facts may not be taken as absolute proof of the Carboniferous age of the Wellesley formation, they nevertheless suggest it strongly, provided the original generic determinations are correct.

CRETACEOUS OR TERTIARY ROCKS

DISTRIBUTION

The distribution of the Cretaceous or Tertiary rocks in the Dennison Fork district is most imperfectly known. From the notes of

$\$$ Brooks, A. H., op. clt., p. 472 . 
Brooks ${ }^{29}$ a small area of such rocks is believed to exist along the north side of the Tanana River a few miles below the Tok River, and this area has been indicated on the map. From reports by prospectors such rocks are also believed to exist somewhere in the valley of Cement Creek and perhaps in the valley of Liberty Creek; but these occurrences have not been seen by the writer, and their positions are not sufficiently well known to justify placing them on the map. Some obscure markings resembling plant remains have also been seen near Mount Fairplay, and a small area of such rocks may possibly be present there.

\section{IITHOLOGY AND STRUOTURE}

Along the Tanana River below the Tok, according to Brooks's field notes, 8 feet of fine yellow sandy shale is exposed on the river bank, overlain by coarse feldspathic sandstone and conglomerate. The grains of the sandstone are rounded, but otherwise the sandstone closely resembles an arkose and must be close to granite, which is believed to be the parent rock. The fine yellow sandy shale contains a few obscure vegetal remains.

In general, these Cretaceous or Tertiary rocks consist of sandstone, shale, and conglomerate and contain also beds of lignitic coal. Just north of the Dennison Fork district these rocks form a part of the bedrock in the valley of Chicken Creek, where they have been examined by the writer. Opposite the town of Chicken they consist of fine-grained cream-colored to yellowish-brown sandstone, drab shale, and beds of conglomerate. The sandstone is loosely consolidated and contains numerous carbonaceous streaks, ferruginous nodules, and here and there angular to subangular pebbles of chert as much as an inch in diameter. The shale is soft and disintegrates rapidly to clay on exposure to the atmosphere. Below Chicken the bedrock has been uncovered along the west side of Chicken Creek by placer mining, and the rocks are seen to be essentially the same. The pebbles of the conglomerate consist of rhyolite, quartz, a green argillaceous tuff, and other types of rock. The shale contains numerous ironstone concretions, in some of which are imperfect impressions of leaves. No coal beds were noted at this locality, but some of the beds of shale are highly carbonaceous.

On Napoleon Creek, likewise in the Fortymile quadrangle, ${ }^{30}$ these rocks unconformably overlie the undifferentiated Paleozoic rocks. The base is a 15-foot breccia, composed of fragments 4 inches or less in diameter of the underlying green phyllitic rocks, with a sandy

Brooks, A. H., op. cit., p. 473.

${ }^{*}$ Prindle, L. M., The Fortymile quadrangle, Yukon-Tanana region, Alaska : U. S. Geol. Survey Bull. 375, pp. 24-25, 1909. 
matrix. Above this is 4 feet of bluish argillaceous rock, overlain by 20 feet of breccia, which in turn is followed by alternating beds of shale and conglomerate.

Everywhere these Tertiary rocks are folded, and at some places they dip at high angles. At the Napoleon Creek locality they were observed by Prindle standing at an angle of $40^{\circ}$; and at the bottom of a shaft near Chicken coal beds stand practically on end. Their unconformable relation to the underlying Paleozoic rocks is unquestionable.

Analyses of the coal from this formation are given on pages $42-43$.

\section{AGE AND CORRELATION}

Within the Dennison Fork district determinable fossils have been found in these rocks only at one locality (5AP178), on Liberty Creek. Here a single piece of matrix about an inch square was obtained by L. M. Prindle. According to F. H. Knowlton, it shows a poorly preserved coniferous branchlet that may belong to Sequoia rigida Heer. If correct, this determination indicates the Cretaceous age of the containing rock.

Some vegetal remains, represented by collections 5AP319 and 5AP319-A, were also found by Prindle somewhere near Mount Fairplay, but the locality is obscure, and the plants are indeterminate.

A short distance north of the Dennison Fork district, in the Fortymile quadrangle, other collections have been made from these rocks. The numbers and localities of these collections, with the determinations by F. H. Knowlton, are given below. All except the last were obtained by Prindle.

3AP224. Irene Gulch, Chicken Creek: Fragments of stems, indeterminable. 3AP2241/2. McDowell claim, Chicken Creek: Equisetum sp.

3AP237. Mouth of creek 1 mile west of Chicken: Plant fragments, indeterminable.

3AP251. Chicken Creek: Fragments of dicotyledons, possibly Corylus macquarrii, but uncertain.

5AK37. Mosquito Fork, about 2 miles above mouth of Chicken Creek; collected by Adolph Knopf: Indeterminate fragments of stems, bark, and coniferous leaves (?).

Still other collections have been made 70 miles to the north, near the Yukon River, and one collection from somewhat similar rocks was made by Prindle and the writer about the same distance to the northwest, in the Circle quadrangle; but these are too distant to have a direct bearing upon the age of the rocks here considered. Excluding these more remote collections, few data of diagnostic value remain in the local collections for any exact age assignment, and such data are conflicting and contradictory. The same condition 
has been noted by the writer ${ }^{31}$ along the Yukon, and in accordance with the compromise in nomenclature there adopted, these rocks. have been designated Cretaceous or Tertiary.

\section{ALLUVIAL DEPOSITS}

Unconsolidated deposits of gravel, sand, and silt are found in all' the trunk valleys and extend up the tributary streams well toward: their headwaters. Plate 2 shows the general distribution of the alluvial deposits, which are in part of Recent and in part of Pleistocene age. The mapping in detail of these two groups will be accomplished only by more detailed studies and the use of a map of larger scale.

The Dennison Fork district north of the Tanana River has not been glaciated, but its physiographic development has been materially influenced by glaciation in the Alaska Range, to the south. All the larger streams entering the Tanana from the south have in their earlier history been glaciated in their headwaters, and the Chisana, Nabesna, Robertson, and Johnson Rivers at the present day head in glaciers. The maximum northern limit to which these glaciers at one time extended has not been accurately determined. According to Brooks ${ }^{32}$ the Robertson River, just above its delta in the Tanana Valley, flows through a canyonlike valley with silt bluffs on each side. On the west side these bluffs are 300 feet high; on the east side they are somewhat lower; and to the north they decrease rapidly in height toward the Tanana, with a corresponding change to still finer sediments. Likewise at the mouth of the Johnson River Brooks noted a bluff 200 feet high composed of fine micaceous sand and silt, containing a few boulders as much as 4 feet in diameter. Brooks believed that these silt deposits containing large boulders were of glacial origin and therefore that glaciers from the Alaska Range extended down the valleys of the Robertson and Johnson Rivers to the Tanana. This conclusion, however, has not been accepted by Capps, ${ }^{38}$ who believes that the glaciers did not quite reach the present Tanana River. Under either hypothesis it is nevertheless true that great outwash deposits of glacio-fluviatile material were swept into the valley of the Tanana River faster than that river could move them downstream. Thus the old valley floor of the Tanana was gradually buried, and the Tanana itself was forced northward against the north wall of its valley where it now flows. As a result of such aggradation a new and higher base-level of erosion was gradually developed for the clear-water streams that enter the

n Mertie, J. B., jr., Geology of the Eagle-Circle district, Alaska : U. 8. Geol. Survey Bull. 816 , pp. $145-146,1930$.

Brooks, A. H., unpublished field notes.

a Capps, S. R., Glaciation of the Alaska Range : Jour. Geology, vol. 20, pl. 1, 1912. $67638-31-3$ 
Tanana from the north, and this in turn has extensively modified the drainage north of the river. With a higher base-level the lower val. leys of streams like Mansfield, George, and Sand Creeks were no longer able to handle their own débris as it moved downstream, and hence these lower valleys were aggraded both by glacio-fluviatile outwash from the south and by fluviatile deposits from the north. The alluvial deposits of the Tanana Valley are therefore a mixture of glacio-fluviatile deposits and of fluviatile and lacustrine deposits of postglacial origin.

An unconsolidated deposit of another type that occurs in the Tanana Valley is volcanic ash. Brooks observed 4 inches of fine white material, which he considered to be volcanic ash, at the top of a 20-foot bluff along the Tanana just below Gardiner Creek; and similarly below the mouth of the Tok River he noted the presence of volcanic ash at the top of a river terrace. Such deposits are a part of the widely distributed ash deposits of this region, which orig. inated, according to Capps, ${ }^{34}$ in the upper valley of the White River. This ash, as shown by its position on top of the other alluvial deposits, was ejected rather recently-in fact, according to Capps, about 1,400 years ago.

The physiographic history of the area north of the Yukon-Tanana divide in the Dennison Fork district in Pleistocene and Recent time is less well understood. The headwater tributaries of the Fortymile are characterized by wide alluvial valleys in their upper courses and constricted valleys downstream, with an abrupt increase in stream gradient at the points where the constricted valleys begin. No wellmarked benches are present in these headwater tributaries of the Fortymile, but in the lower valleys several systems of benches have been developed, of which the highest one, due allowance being made for the old stream gradient, represents the old base-level of erosion, which is still preserved in the headwater flats. Here is clearly an example of stream rejuvenation, caused by lowering of the base-level of the Fortymile River, perhaps in several successive stages. The cause of this rejuvenation and the details of its development remain as problems for the future.

Plate $5, B$, which is a view looking up the valley of Mosquito Fork from the confluence of Mosquito and Dennison Forks, shows a welldeveloped high bench on both sides of Mosquito Fork. To the left the same terrace may be recognized in the lower valley of Dennison Fork.

The most difficult matter to understand, however, is the excessive width and extraordinarily low gradient of these headwater stretches

3 Capps, S. R., An ancient volcanic eruption in the upper Yukon basin, Alaska : U. S. Geol. Survey Pror. Paper 95, pp. 59-64, 1915. 
of the Mosquito and Dennison Forks of the Fortymile. A considerable part of the alluvium in these depressions consists of sand and gravel and gives every evidence that it was eroded from the surrounding hills, transported downstream, and accumulated slowly in the main valleys. The trunk streams were evidently unable to handle the débris fed in by the tributary streams, but no evidence is available to show that this aggradation was due to excessive headwater fluviatile activity, producing an excess of débris, as in the Tanana Valley. Some local process apparently raised the base-level of the trunk streams to such an extent that they were unable to handle even a normal supply of débris, and the only explanation that can be advanced at present to account for this condition is local warping to the north. Such warping of the country rock, however, must be of ancient origin and long antedates the relatively late rejuvenation of the Fortymile River. It is likely, in fact, that this process dates back to the early Pleistocene, and a considerable part of these headwater alluvial deposits are therefore considered to be of Pleistocene age.

The alluvial deposits of Recent age in the valleys of the Mosquito and Dennison Forks of the Fortymile River and along the Ladue River are composed of gravel, sand, and silt that have been deposited nnder the ordinary conditions of stream erosion. On account of the conditions that prevail in the upper parts of the Mosquito and Dennison Forks, such deposits are found mainly as a veneer lying above the older débris in these flats and in the extreme headwater portions of these streams. In the lower constricted valleys the present stream beds are composed mainly of coarse gravel.

Most of the hill slopes in this district are mantled by rubble, which merges downhill into the ordinary stream deposits. The production of these alluvial deposits by the action of solifluxion and related processes and by alternate thawing and freezing constitutes an important part of the general process of erosion in this region.

\section{IGNEOUS ROCKS}

\section{GREENSTONE}

\section{DISTRIBUTION}

Rocks that have been described by Brooks ${ }^{35}$ as greenstone schist are found in the southeastern part of the Dennison Fork district between Scottie and Mirror Creelss and along the north side of the Tanana River below Gardiner Creek. The distributiton of these rocks, as shown in Plate 2, is based upon the earlier mapping by Brooks and will probably require modification in the future.

\footnotetext{
${ }^{25}$ Brooks, A. H., A reconnaissance in the Tanana and White River basins, Alaska, in 1898: U. S. Geol. Survey Twentieth Ann. Rept., pt. 7. p. 470, 1900.
} 


\section{PETROGRAPHIO OHARAOTER}

Ten thin sections of rocks from this group, collected by Brooks, have been examined under the microscope and constitute the basis for the following descriptive data. Four types of rocks are represented-namely, gabbro, diabase, basalt, and ultrabasic rocks-all much altered, with the consequent development of a greenstone habit.

The gabbro is a coarse-grained hypidiomorphic granular rock composed essentially of kaolinized plagioclase feldspar, pyroxene largely altered to chloritic products, and iron hydroxides. In one or two specimens the original rock-forming minerals have been completely replaced by secondary minerals, such as quartz, chlorite, calcite, and epidote. The diabasic and basaltic greenstones differ from the gabbroic greenstone mainly in their finer granularity and different fabric and on the whole are less altered than the gabbroic rocks. Chlorite, calcite, and quartz are the main secondary minerals. Three specimens of ultrabasic greenstone consist essentially of olivine, with a considerable percentage of magnetite or ilmenite in elongated patches along lines of cleavage. Actinolite is an abundant constituent of one of these specimens. Brooks also mentioned the presence among this assemblage of dioritic greenstone (metadiorite) and tuffaceous greenstone. The tuffaceous rock is of a rather acidic type and may more properly belong with some of the Mesozoic volcanic rocks.

\section{AGE AND OORRELATION}

Brooks apparently regarded these rocks as mainly of intrusive origin and noted that they occur close to the contact between the "Tanana schists" (undifferentiated Paleozoic rocks) and the "Gneissic series" (Pelly gneiss). Dikes of the same general type are found in the Birch Creek schist, the Pelly gneiss, and the undifferentiated Paleozoic rocks. On the other hand, these rocks originated before the Wellesley formation was deposited, as pebbles of the greenstone constitute a considerable part of the basal conglomerate of that formation. It is certain, therefore, that these greenstones are of pre-Wellesley age and later than the undifferentiated Paleozoic rocks, which are probably in the main Silurian. Probably much of this greenstone originated during the Devonian period, but some of it may be of early Carboniferous age.

\section{GRANITIC ROCKS}

\section{DISTRIBUTION}

Granitic rocks are widely distributed in the Dennison Fork district. Moreover, they are closely intermingled with the rhyolite and dacite porphyries at many places, and it is therefore obvious that a 
complete separation between these two major types could not be made in a rapid reconnaissance of an area as large as the Dennison Fork district. Also, without doubt, smaller bodies of granitic rocks which intrude the Birch Creek schist and associated rocks, particularly in the northeastern part of the district, have not been mapped. Finally, the mapping of the granitic rocks along the Tanana is based mainly upon the notes of Brooks, from his traverse of 1898 . In general, therefore, the mapping of the granitic rocks as shown on Plate 2 must be regarded as tentative and subject to considerable alteration by later work.

One large area of granitic rocks lies between the Mosquito and Dennison Forks of the Fortymile River, centering about Taylor Mountain. Another large area, which lies west of Kechumstuk Mountain, extends southwestward for about 15 miles and probably continues northwestward for 30 miles to the edge of the district. The continuity of this area across the head of Sand Creek, however, to connect with the granitic area at the head of the Healy River, is doubtful. Another area of considerable size lies between the head of the Dennison Fork of the Fortymile and the head of the West Fork of the Ladue River. The notes and specimens of Brooks show granitic rocks almost continuously from Tanana Crossing to Sand Creek, and on the basis of these data the large area between Mansfield and Sand Creeks has been indicated. Brooks's notes also indicate the presence of granitic rocks on the north side of the Tanana opposite the mouth of the Tok River. Smaller areas of granitic rocks have elsewhere been shown, as at Mount Fairplay and among the Birch Creek schist and associated rocks in the basins of the East Fork of the Dennison Fork and the Ladue River.

\section{PETROGRAPHIO CHARACTER}

The granitic rocks consist principally of granite and quartz diorite but include also some quartz monzonite, as well as acidic and basic differentiates of the granitic magma. Most of the granitic rocks are coarse-grained, hypidiomorphic granular rocks, but porphyritic varieties are also found, especially as dikes and along the borders of the larger intrusive masses. The common mineral constituents are quartz, potash, and soda-lime feldspars in varying proportions, biotite, and hornblende, with a number of accessory minerals. Detailed work will be necessary in this district to map separately the different petrographic types.

Granite.-The most common of the granitic rocks is biotite granite. This is a dark-gray hypidiomorphic rock, some of it with a slight greenish hue due to chloritization of the biotite. The mineral constituents are quartz, orthoclase (rarely microcline), plagioclase, and biotite, with apatite and zircon as the common accessory minerals. 
Locally garnet also is present. Orthoclase in some specimens is graphically intergrown with quartz. Plagioclase constitutes from 5 to 30 per cent of the feldspar content and has about the composition of oligoclase, though ranging from albite to acidic andesine. Titan: ite and magnetite also occur as accessory minerals, but chiefly where hornblende is also present and the granite tends to be somewhat more basic. Highly potassic biotite granite occurs among the granitic rocks in the 4,000-foot dome southeast of the forks of the Ladue River. Such granite consists of orthoclase, microcline, little or no plagioclase, chloritized biotite, and some epidote; similar rocks are found along the north side of the Tanana a few miles below the mouth of the Tok River. Most of the biotite granite is fresh and unaltered, but the effects of secondary processes are apparent in some of these rocks. The plagioclase is in some specimens more or less sericitized, and the biotite is altered to chloritic minerals and epidote.

Muscovite also is found at some places in association with biotite, producing muscovite-biotite granite, but only a few specimens of true muscovite granite have been seen. The muscovite-biotite and muscovite granites occur mainly in association with alaskitic and aplitic rocks, as dikes of later origin than the main granitic masses.

By a gradual decrease in the amount of biotite and a corresponding increase in the amount of hornblende, the biotite granite grades into hornblende granite. Many of these granites therefore contain both biotite and hornblende and are in reality biotite-hornblende granites. Only a few true hornblende granites were seen, and these occur mainly in the granitic mass west and northwest of Wolf Creek.

More specialized types of granite are also found, including mainly alaskite, aplite, and tourmaline granite. Alaskite was seen at the head of Wolf Creek and at the head of Mosquito Fork, and similar rock was identified among the granitic rocks collected by Brooks along the Tanana below the Tok River. These rocks have the same texture as the biotite granite but differ in the absence of mafic minerals and the presence of only a very small percentage of plagioclase feldspar. Aplite was observed at the head of the East Fork of the Dennison Fork and along the northeast side of the Tanana between Johnson and Gerstle Rivers. Such rocks have a fine, equigranular fabric and consist of quartz, orthoclase, acidic oligoclase, biotite, and muscovite; in places they contain also clear pink garnets. Tourmaline was seen at several places in the granites, but only one specimen of a true tourmaline granite is known in this area. This rock, which was collected by L. M. Prindle in 1905 from float in Liberty Creek, consists of quartz, orthoclase, oligoclase, tourmaline, apatite, and zircon and is believed to be of pegmatitic origin. Another interesting rock 
is a greisen which occurs among the granitic rocks at the west side of Mount Fairplay. This is composed essentially of quartz and muscovite, with accessory tourmaline, hematite, and zircon. It contains no feldspar.

Quartz diorite.-Quartz diorite is second in abundance among the granitic rocks of this district. It is found in association with biotite and biotite-hornblende granite in the larger granitic areas but is not known to occur alone in any large areas. These rocks in general are darker than the granites, owing to a larger proportion of mafic minerals, but they have the same general texture. They consist of quartz, plagioclase, orthoclase, hornblende, and biotite and the accessory minerals apatite, titanite, magnetite, ilmenite, and zircon. The plagioclase feldspar has about the composition of andesine and is locally much altered to sericite and epidote. The proportion of potash feldspar ranges from 15 per cent down; many of these rocks contain none. Hornblende is the main mafic mineral, but biotite is also very prevalent, and in a few of these rocks hornblende is absent, the rocks thus being quartz-biotite diorites. In one specimen neither hornblende nor mica occurs, their place being taken by epidote, which is probably secondary after hornblende. Augite diorite was also noted among the granitic rocks west of Wolf Creek. Such rocks have no quartz and consist of andesine, orthoclase, augite, and biotite, together with apatite, titanite, and magnetite. A little epidote is also developed.

Quartz monzonite.-In view of the apparent gradation between the granites and the quartz diorites, the scarcity of monzonitic rocks is rather noteworthy. Practically none of the granitic rocks collected by Prindle in 1905 and by the writer in 1928 appear to belong to the monzonite family, but a number of the rocks collected by Brooks along the Tanana River, particularly from the mouth of the Tok River downstream, are quartz monzonites. These rocks consist of quartz, orthoclase and plagioclase in more or less equal proportions, biotite, hornblende, and in one specimen augite, together with the usual accessory minerals apatite, titanite, and iron oxides. The plagioclase feldspar ranges from basic oligoclase to andesine.

Gabbro.-Basic differentiates of the granitic magma also occur in this area but are relatively rare. One specimen of this type was collected by Prindle at the east side of the granitic area west of Kechumstuk Mountain. This is a true gabbro, consisting of plagioclase, augite, a little biotite, apatite, and magnetite. The plagioclase is zonally grown, with rims of andesine and centers of bytownite, and has an average composition of about acidic labradorite. Another specimen collected by Brooks along the Tanana just below the Tok River is an olivine gabbro. Other basic and even ultrabasic 
rocks, however, have been found in association with the granitic rocks in the Circle quadrangle, to the north, and it is probable that a careful survey will reveal more rocks of this type in the Dennison Fork district.

\section{AGE AND OORRELATION}

No data are available in the Dennison Fork district for determining exactly the geologic age of the granitic rocks. They are known to intrude the Birch Creek schist, the Pelly gneiss, and the undifferentiated Paleozoic rocks, and elsewhere in interior Alaska similar rocks are known to intrude the later Paleozoic rocks. To the north, in the Circle quadrangle, granitic boulders were found by Prindle ${ }^{36}$ and the writer in a conglomerate, which was determined to be of Upper Cretaceous (?) age. Hence these granitic rocks are believed to be mainly older than Upper Cretaceous. Jurassic rocks have not been found in interior Alaska. The Lower Cretaceous Kandik formation along the Yukon River ${ }^{37}$ contains conglomerate in its upper part, but no granitic pebbles were noticed, although these rocks lie at no great distance north of a large area of granitic rocks. These granitic rocks, of course, may have been intruded before the Lower Cretaceous epoch but may not have been exposed at the surface until after the deposition of the Lower Cretaceous sediments. From the known facts it appears that the granitic rocks were intruded some time in the Mesozoic era prior to the Upper Cretaceous epoch. The Coast Range batholith of granitic rocks, as seen in southeastern Alaska and in the Alaska Range, is generally regarded as Jurassic or Cretaceous, and most of the granitic rocks of the Yukon-Tanana region are believed to belong to the same period of intrusion.

It is well known, however, that some of the granitic rocks of the Yukon-Tanana region have intruded Upper Cretaceous rocks, as in the Rampart district, and are probably of Tertiary age. One of the criteria heretofore used by the writer for recognizing the Tertiary granitic rocks, where stratigraphic data are lacking, is the occurrence of cinnabar in association with the granite. Cinnabar is found in small quantities in some of the creeks of the Fortymile mining precinct, to the north-for example, in Franklin Gulch and in Stonehouse and Jack Wade Creeks. Also it is reported by Cockfield ${ }^{38}$ from the placer workings on the Sixtymile River. Hence a probability exists that some of the granitic rocks of this area may be of Tertiary age.

* Prindle. L. M., A geologic reconnaissance in the Circle quadrangle, Alaska : U. S. Geol. Survey Bull. 538, p. 32, 1913.

st Mertie, J. B.. jr., Geology of the Eagle-Circle district, Alaska: U. S. Geol. Survey Bull. 816, pp. 136-141, 1929.

ss Cockfleld, W. E., Sixtymile and Ladus River area, Yukon Territory : Canada Geol. Survey Jem. 123, p. 52, 1921. 


\section{EARLIER VOLCANIC ROCKS}

\section{DISTRIBUTION}

Rocks that are believed to be largely of surficial origin are widely distributed in the headwaters of the Dennison Fork of the Fortymile, from Mount Fairplay and vicinity southwestward to the Tanana River. An area of about 800 square miles is covered mainly by rocks of this type. The earlier volcanic rocks are intermingled with the granitic rocks in such an intimate way as to suggest their consanguineous origin. This relation makes it difficult to effect a cartographic separation of these two types of igneous rocks, especially in reconnaissance work, where many localities can not be visited. Hence, in more detailed mapping of this district, areas of granitic rocks that are not shown on Plate 2 will undoubterly be found in this volcanic field.

\section{PETROGRAPHIC CHARACTER}

Three general types are represented among the earlier yolcanic rocks-namely, rhyolitic, dacitic, and basaltic rocks. The rhyolitic rocks are the most numerous, and the basaltic rocks the least. Refined geologic study, both in field and office, will be required to separate these three types into mappable formations.

Rhyolitic rocks.-The rhyolitic rocks consist of rhyolite and rhyolite porphyry; the porphyritic varieties are the more common. The groundmass of both porphyritic and nonporphyritic varieties is usually aphanitic, although the character of the principal mafic mineral may often be discerned. Under the microscope, however, most of the rhyolitic rocks are seen to be holocrystalline, relatively few of these rocks having any considerable proportion of glass in the matrix. The most common type of rhyolite and rhyolite porphyry consists of quartz, orthoclase, acidic plagioclase, and biotite, with the accessory minerals apatite, titanite, zircon, magnetite, ilmenite, and locally garnet.

Where these rocks are porphyritic the phenocrysts are usually quartz and feldspar, either orthoclase or plagioclase and in some specimens both. Magmatic corrosion of the phenocrysts is noticeable in some of these rocks. The groundmass is usually a finely granular matte of quartz and orthoclase, with a minor proportion of plagioclase. Graphic intergrowths of quartz and orthoclase are not uncommon, and spherulitic orthoclase is present here and there. The plagioclase, in both phenocrysts and groundmass, has the average composition of basic oligoclase, but the phenocrysts of plagioclase are as a rule zonally grown and show a considerable range in composition from rims to centers. Much of the biotite is more or less 
altered to chloritic minerals and epidote. Muscovite occurs also as one of the primary minerals but is less abundant than biotite. Hornblende is rare. The common secondary minerals are chlorite, sericite, epidote, and calcite.

A more specialized type of rhyolite was observed at several localities. This is a sodic rhyolite, some of it porphyritic and some nonporphyritic, consisting mainly of quartz, albite, and biotite or locally hornblende. In much of the porphyritic rock the phenocrysts are corroded orthoclase. The groundmass is a fine intergrowth of quartz and albite.

Dacitic rocks.-The dacitic rocks, like the rhyolitic rocks, include both porphyritic and nonporphyritic varieties and may well be regarded as the surficial equivalents of the quartz diorite. They much resemble the rhyolitic rocks but on the whole are darker and seem to be more altered. Tuffaceous varieties were also seen. The rock constituents are chiefly quartz, plagioclase, biotite, and hornblende. Orthoclase is relatively scarce. The plagioclase, about andesine, is usually much sericitized, and the mafic minerals biotite and hornblende are nearly everywhere altered to chlorite, epidote, and other secondary products. Apatite, titanite, and iron oxides are the principal accessory minerals.

Basaltic rocks.-Basaltic rocks, though relatively rare, also appear to constitute a part of this retinue of volcanic rocks. Most of these are porphyritic, consisting of phenocrysts of plagioclase and augite in a matrix of plagioclase, augite, iron oxides, and rarely biotite. The plagioclase has the composition of labradorite. Some of the augite is chloritized, but on the whole these rocks are less altered than the dacitic rocks and may well be of later age.

\section{AGE AND CORRELATION}

Rhyolitic and dacitic rocks from the Circle quadrangle were described by Prindle ${ }^{39}$ and the writer in 1911 and were at that time considered to be subsequent to at least part of the Cretaceous sediments and probably of Tertiary age. One of the criteria for this conclusion was the observed superposition of these lavas upon the Mesozoic granitic intrusive rocks in mesa-like distribution. Another was the observed intrusive relation of these rocks to the Cretaceous (?) conglomerate.

Similar rocks occur in the Dennison Fork district, but here equally good age data have not been collected. In particular, the porphyries have not been observed overlying the granitic rocks but seem rather to be irregularly intermingled with them. Nevertheless, it is believed

\footnotetext{
^ Prindle, L. M., A geologic reconnaissance of the Circle quadrangle, Alaska : U. S.
} Geol. Survey Bull. 538, pp. 36-48, 1913. 
from the petrographic similarity that these porphyries are exactly correlative with the rhyolite and dacite porphyries observed in the Circle quadrangle, and they are therefore here assigned to the late Mesozoic or early Tertiary.

\section{LATER VOLCANIC ROCKS}

\section{DISTRIBUTION AND OCOURRENOE}

The rocks here described as later volcanic rocks are scarce in the Dennison Fork district. The principal area is a narrow belt between the main forks of the Ladue River that extends eastward across the international boundary into Yukon Territory. The continuation of this belt has been mapped and described by Cockfield..$^{40}$

These rocks, which comprise both lavas and tuffs, strike a little north of west and crop out in a belt about 2 miles wide over a distance of 14 miles in Alaska and 4 miles farther east in Yukon Territory. At one point about 10 miles west of the international boundary, along the south side of this belt, the lavas may be plainly seen in bedded sequence, dipping about $30^{\circ} \mathrm{N}$. Twenty-five beds of lava and tuff were counted, and after making due allowance for covered zones on the hillslope, the writer believes that at least 40 beds are present at this locality, with a total thickness of about 600 feet. This is by no means a measure of the total thickness of the formation. If the same dip continues northward to the limit of these rocks, the total thickness may well be several times as great, but of this there is no direct evidence, as the exposures on the north slopes are not good. It seems quite probable, however, even if the structure is reversed, that this formation may embrace 2,000 feet of lava and tuff.

Two other small areas of basic rocks occur north of the East Fork of the Dennison Fork. The more northerly of these comprises two small hogbacks of basaltic rock, which are probably late lava flows. The more southerly area is a little volcanic cone, with a well-developed crater, which likewise must be relatively young, as it is but little dissected. This crater is illustrated in Plate $8, B$.

\section{PETROGRAPHIC CHARACTER}

The main belt of volcanic rocks above described consists of lavas of several kinds and subaerial tuffs and flow breccias. Rhyolite, dacite, and basalt were observed in such close relations with one another as to suggest their nearly contemporaneous origin. All these rocks are porphyritic, and some of them are partly glassy, but aside from that they have no particular petrographic characteristics that

\footnotetext{
${ }^{\infty}$ Cockfield, W. E., Sixtymile and Ladue River areas, Yukon: Canada Geol. Survey Mem. 123, pp. 31-33, 1921.

LIET:PY
} 
merit special description. Banded tuffs are prominent, as they weather to various shades of brown and red. At the volcanic crater above described the main lava is a normal basalt, but ultrabasic inclu. sions of lherzolite and websterite are also found in these lavas.

\section{AGE AND CORRELATION}

These lavas are undoubtedly of several ages. The lavas and tuffs of the main belt between the forks of the Ladue River are believed to be post-Eocene and have been considered by Cockfield ${ }^{41}$ to be postMiocene. The volcanic cone to the north, however, is so well preserved that it may well be of Recent age. In general, therefore, it appears that volcanism has occurred in this region intermittently but in diminishing volume from the early Tertiary almost if not quite to Recent time.

\section{MINERAL RESOURCES}

No mining has been done in the Dennison Fork district, and there is little evidence of much prospecting. On account of the remoteness of this district from established centers of communication, it is probable that the development of gold placers would constitute the only profitable kind of mining at the present time. Gold lodes might possibly be developed, but they would have to be of bonanza type to warrant their exploitation under present conditions of transportation. The mining and shipment of sulphide ores of the base metals at a profit is obviously impossible.

Of recent years it has become axiomatic in interior Alaska that where granitic rocks occur the possibility exists of finding metalliferous deposits, particularly of gold. This dependence of mineralization upon granitic intrusion is evident in the mining camps of the Yukon-Tanana region and therefore should constitute a starting point for prospectors in searching for new deposits of lode and placer gold. This generalization is also a very practical one, because every prospector is able to recognize the granitic rocks at sight, though he may not be able to distinguish the several classes that are based upon microscopic determination. What, then, are the practical limitations of this conclusion, and how may it be applied in this area?

First, gold does not occur invariably with all types or with any particular type of granitic rocks. Many granitic intrusions have apparently caused no mineralization of economic importance. On the other hand, the mere fact that gold mineralization is dependent, under restricted conditions, upon granitic intrusion automatically excludes much territory where it would be useless to prospect, thus restricting the areas of possible importance and rendering easier the selection of areas of promise. With much unfavorable territory thus

« Cockfleld, W. E., op. cit., p. 34. 
eliminated, what further guidance may be given to the prospector? In general, it is believed that gold-bearing solutions escaped from the granitic magma in a late stage of its cooling process, migrated upward, and were deposited at or near the apexes of such granitic bodies, sometimes in the granite itself but often in the surrounding country rock. Hence it should be remembered that the character of the country rock itself is of little importance, provided the granitic intrusive rocks are present.

Among many prospectors in interior Alaska the idea persists that a country rock of schist is indispensable for the occurrence of gold. This fallacy is due to the purely fortuitous fact that some of the larger mining camps, such as Klondike, Fortymile, Fairbanks, Koyukuk, and Nome, have been located upon a bedrock of schist. The schist of interior Alaska is largely a metamorphic sedimentary rock, and unless it is mineralized it is no more likely than any other country rock to carry gold. Mineralization was accomplished in areas both of schist and of other country rock, by solutions which formed gold quartz veins and which originated from granitic rocks.

As gold quartz veins are most likely to be found at or near the apexes of granitic intrusive bodies, such places should be chosen to prospect. Most granitic intrusive bodies are believed to diminish upward in size, so that the presence of a large area of granitic rocks at the surface is likely to signify that the upper or mineralized zone of the original mass has been removed by erosion. Conversely, the occurrence of a small area of granite is likely to signify that such a mineralized zone, if originally present, is still intact. It follows that large areas of granitic rocks are less favorable sites for prospecting, whereas the smaller areas are especially favorable. Quartz veins should be carefully noted and prospected, however, whether or not granite is exposed near by, because in some localities the granitic magma has risen near enough to the surface to produce surficial mineralization without being itself exposed to view.

The considerations above outlined are directly applicable to lode prospecting but are just as applicable to prospecting for placer deposits, as the gold must first be present in lode form before it can be eroded and concentrated by stream action into placer deposits. From one point of view these considerations are of even more importance to the prospector for placer ground, because workable placers may be developed from very lean as well as from high-grade lode deposits, and obviously low-grade ores are more prevalent than high-grade ores. Hence sites that might be of little value for lode mining might well be of great value as sources of placer gold, if concentration of the gold had been highly developed by stream action.

In general, therefore, the lode prospector should search at and about areas where small bodies of granitic rocks are exposed at the 
surface, or where quartz veins are especially prevalent; and the placer prospector should search in particular the streams that drain such areas. On applying these ideas to the Dennison Fork district, it appears that the western half, because of the large bodies of granitic rocks there present, is not particularly favorable for the occurrence of gold ores. On the other hand, the northeastern part, particularly in the headwaters of Liberty Creek, the Sixtymile River, the East Fork of the Dennison Fork, and the Ladue River, constitutes an area well worth prospecting, because small bodies of granitic rocks are there well developed. Only a few of these bodies have been indicated on the map, because the reconnaissance nature of this work has not permitted their mapping in detail. In particular, the possible occurrence of bench placers should not be overlooked, for conditions favorable for the concentration of placers seem on the whole to have been more favorable in interior Alaska in Pleistocene time than at present. This fact is well attested by the dominant importance of bench placers in the mining camps of the Yukon-Tanana region.

Another mineral resource of this district is low-grade coal, which, although of no value for export, is utilized for local needs-for example, in blacksmithing work. About a quarter of a mile west of Chicken this coal has been opened by a 35-foot shaft, at the bottom of which a tunnel has been run south for 60 feet. A room 14 feet high, 10 feet wide, and 60 feet long has been excavated, and 22 feet of coal is there exposed, striking N. $65^{\circ}$ E. and standing vertical. Neither the top nor the bottom of the coal bed is exposed. Two samples of this coal were taken for analysis, one an average of the bed and the other from a narrow seam of bright shiny coal, apparently of higher grade than the average. Proximate analyses of these samples were made by H. M. Cooper, of the Bureau of Mines, with the following results:

\section{Analyses of lignitic coal from Chicken}

Average of coal bed

[Air-dry loss, 8.9 per cent]

\begin{tabular}{|c|c|c|c|c|}
\hline & Air dried & As received & $\begin{array}{l}\text { Moisture } \\
\text { free }\end{array}$ & $\begin{array}{l}\text { Moisture } \\
\text { and ash free }\end{array}$ \\
\hline \multirow[t]{2}{*}{$\begin{array}{l}\text { Moisture... } \\
\text { Volatile matter. } \\
\text { Fired carbon. } \\
\text { Ash }\end{array}$} & $\begin{array}{l}15.5 \\
33.8 \\
39.3 \\
11.4\end{array}$ & $\begin{array}{l}23.1 \\
30.8 \\
35.7 \\
10.4\end{array}$ & $\begin{array}{l}40.0 \\
46.5 \\
13.5\end{array}$ & $\begin{array}{r}46.2 \\
53.8 \\
\end{array}$ \\
\hline & 100.0 & 100.0 & 100.0 & 100.0 \\
\hline Sulphur.... & .5 & .4 & .6 & .7 \\
\hline $\begin{array}{l}\text { Calories } \\
\text { British thermal units. }\end{array}$ & $\begin{array}{l}5,083 \\
9,150\end{array}$ & $\begin{array}{l}4,628 \\
8,330\end{array}$ & $\begin{array}{r}6,017 \\
10,830\end{array}$ & $\begin{array}{r}6,950 \\
12,510\end{array}$ \\
\hline
\end{tabular}


Analyses of lignitic coal from Chicken-Continued

Picked sample

[Air-dry loss, 2.6 per cent]

\begin{tabular}{|c|c|c|c|c|}
\hline \multirow[t]{2}{*}{$\begin{array}{l}\text { Moisture. } \\
\text { Volatile matter. } \\
\text { Fixed carbon. } \\
\text { Ash. }\end{array}$} & $\begin{array}{r}10.3 \\
36.4 \\
49.0 \\
4.3\end{array}$ & $\begin{array}{r}12.6 \\
35.4 \\
47.8 \\
4.2\end{array}$ & $\begin{array}{r}40.6 \\
54.6 \\
4.8\end{array}$ & $\begin{array}{r}42.6 \\
57.4 \\
-7.8\end{array}$ \\
\hline & 100.0 & 100.0 & 100.0 & 100.0 \\
\hline Sulphur.- ........ & .5 & .5 & .6 & .6 \\
\hline $\begin{array}{l}\text { Calories } \\
\text { British thermal units }\end{array}$ & $\begin{array}{r}5,906 \\
10,630\end{array}$ & $\begin{array}{r}5,750 \\
10,350\end{array}$ & $\begin{array}{r}6,583 \\
11,850\end{array}$ & $\begin{array}{r}6,911 \\
12,440\end{array}$ \\
\hline
\end{tabular}

The run-of-mine sample must evidently be classified as lignite. As received, the picked sample of higher-grade coal ranks 33 per cent higher in fixed carbon, 24 per cent higher in calorific value, and 45 per cent lower in moisture and is really a subbituminous coal of average grade, comparable with some of the subbituminous coals of the Rocky Mountain States. 


\section{INDEX}

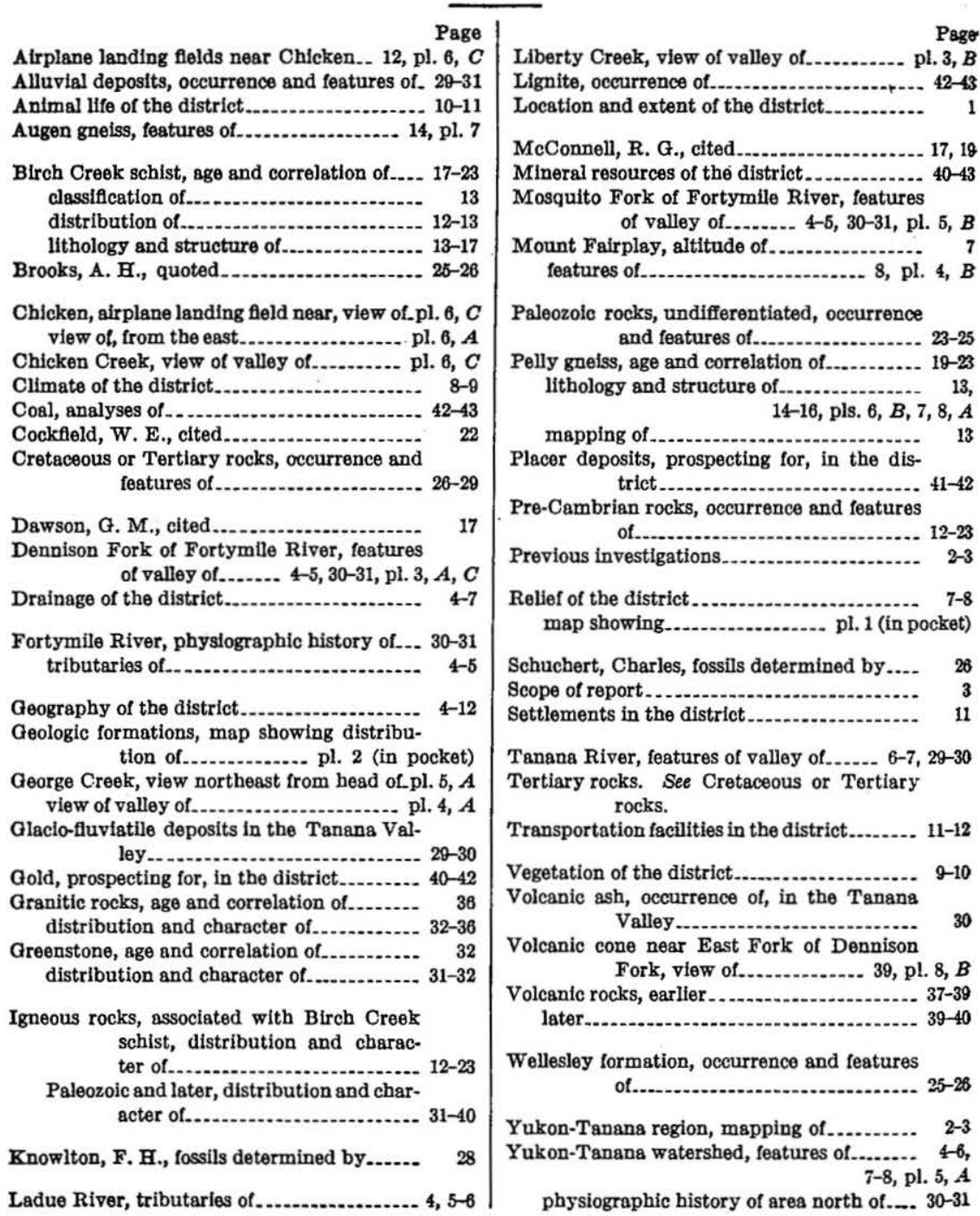






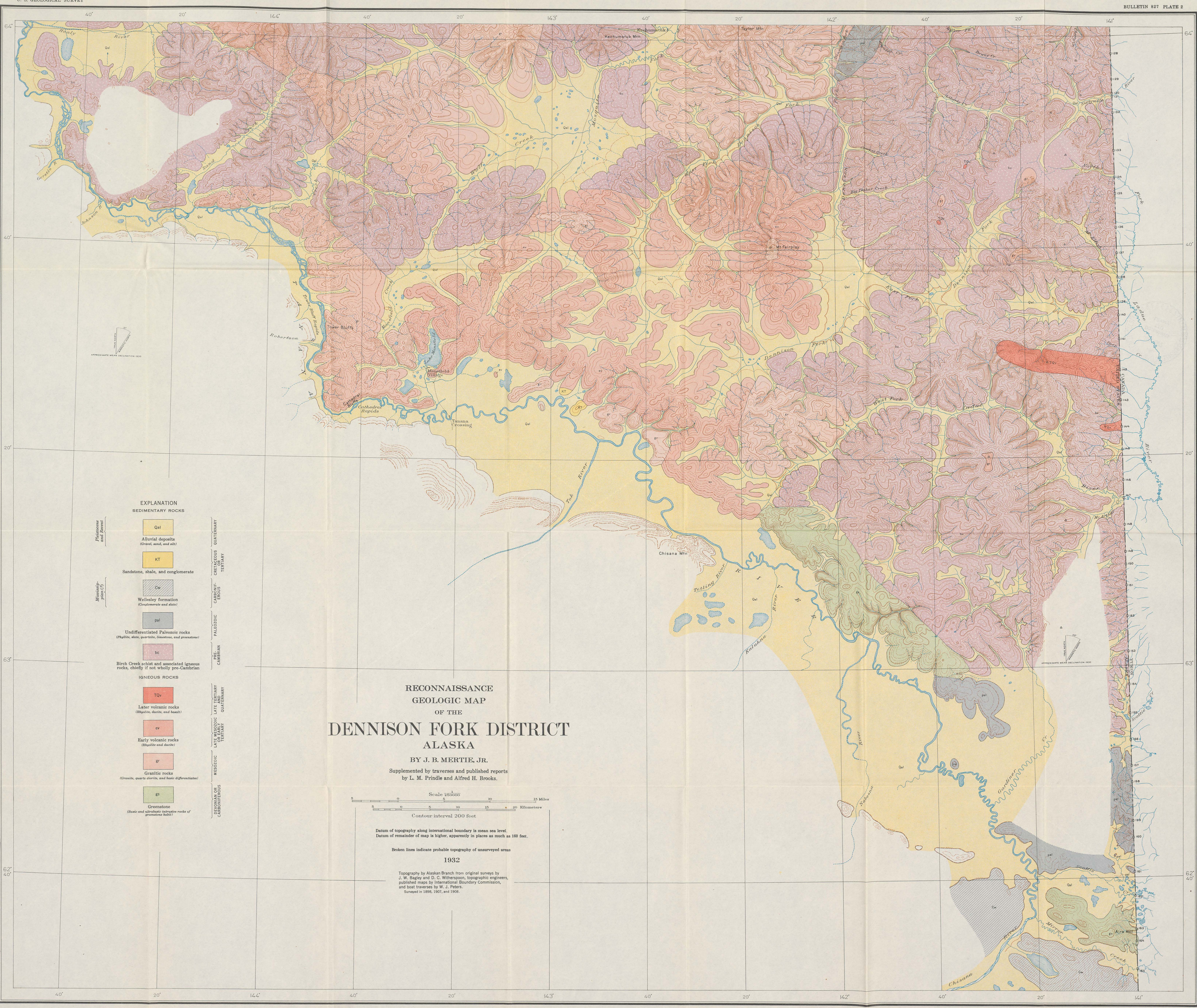




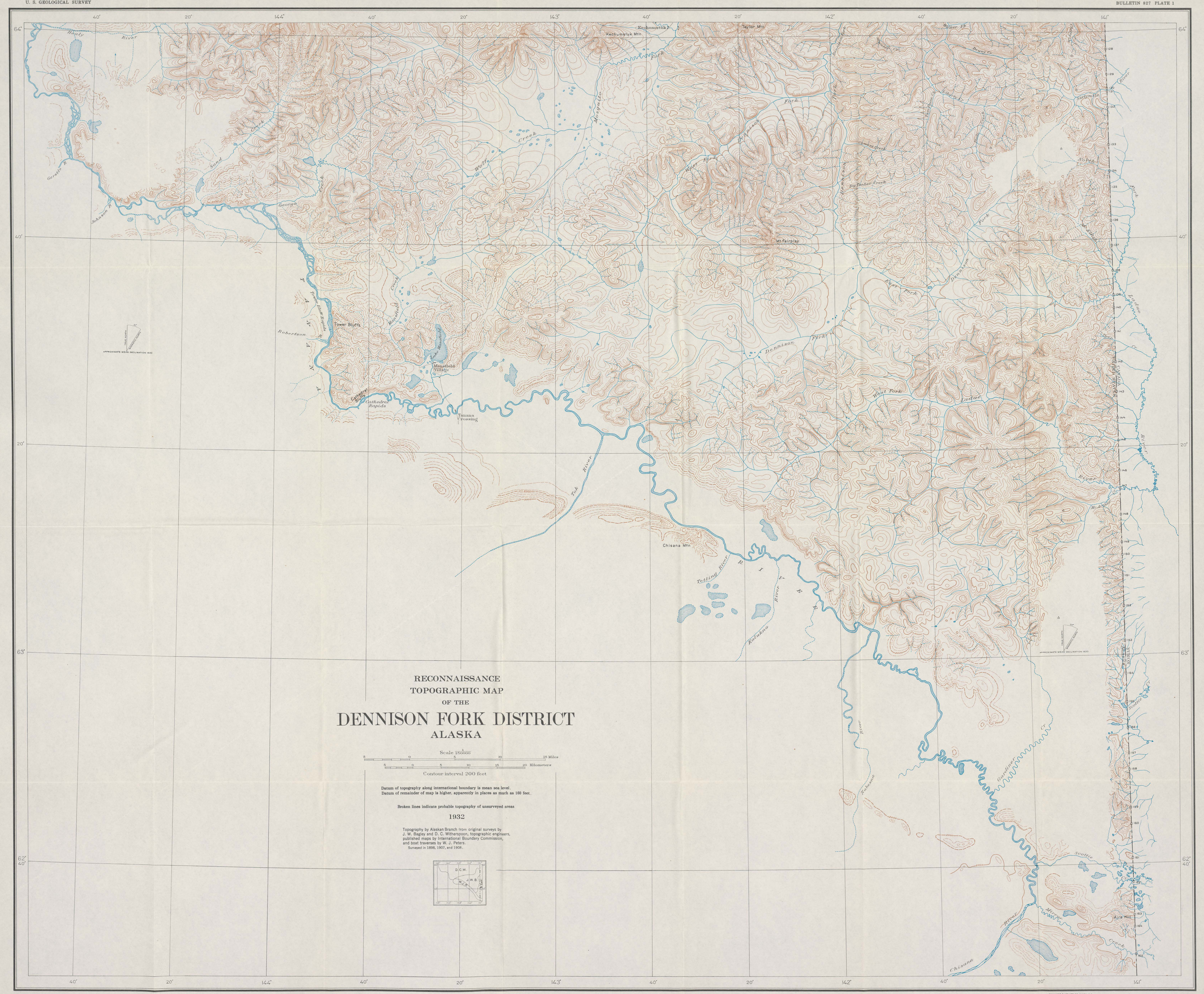



